\title{
Preparation and chemical reactivity of 2-chromanols
}

\author{
Jean-Marc R. Mattalia* and Mireille M. Attolini \\ Aix Marseille Université, CNRS, iSm2 UMR 7313, 13397, Marseille, France \\ E-mail: jean-marc.mattalia@univ-amu.fr
}

\begin{abstract}
This review describes the preparation and chemical reactivity of 2-chromanols. These derivatives appear as interesting intermediates in the synthesis of various natural products and biologically active compounds.
\end{abstract}

Keywords: 2-chromanols, synthesis, chemical reactivity, biological activity

\section{Table of Contents}

1. Introduction

2. Preparation of 2-Chromanol Derivatives: General Methods

2.1 Reduction of dihydrocoumarins by aluminum hydrides

2.2 Titanocene-catalyzed reduction of dihydrocoumarin

2.3 Double reduction of coumarins into 2-chromanols

2.4 Lactols from acetals

2.5 Intramolecular lactolization

2.5.1 Hydroformylation of protected 2-hydroxystyrene derivatives

2.5.2 Palladium-catalyzed conjugate addition

2.5.3 Asymmetric reactions of $\beta$-(2-hydroxyaryl)- $\alpha, \beta$-unsaturated ketones and $o$-hydroxycinnamaldehydes with organoboronic acids

2.5.4 Asymmetric reactions of $(E)$-2-(2-nitrovinyl)phenols with carbonyl compounds

3. Reactions of the Cyclic Form of 2-Chromanol Derivatives

3.1 Deoxygenative reduction

3.2 Elimination

3.3 Oxidation

3.4 Substitution reactions. Formation of acetals

4. Reactions of the Open Form

4.1 Reactions of the phenol group

4.2 Addition of carbon nucleophiles 
4.2.1 Organometallics. Transition metal catalyst

4.2.2 Wittig reaction

4.2.3 Knoevenagel condensation

4.3 Addition of amines

4.3.1 Reductive amination

4.3.2 Domino reaction

4.4 Hydride reduction

5. Conclusions

6. References

\section{Introduction}

Substituted chromans, or more precisely chromanol-containing compounds, are a class of benzopyran derivatives frequently found in biologically active natural products such as vitamin $\mathrm{E}$ (or tocopherol) or flavanol. Many chromanol and chroman derivatives have been studied and exhibit a variety of activities, including antioxidant ${ }^{1,2}$ or antibacterial ${ }^{3,4}$ properties. The 2chromanol moiety $\mathbf{1}$ appears as an interesting precursor of the above class of compounds and related chromenes but also of various diarylmethanes and sesquiterpenes.



2-chromanol 1

This review provides an overview of the synthesis and reactivity of 2-chromanol derivatives. In the first part, we intend to outline the general methods by which the 2-chromanol derivatives are prepared. More detailed preparations will be described in sections 3 and 4 . The second and third parts are devoted to the chemical reactivity of the 2-chromanol derivatives. We do not intend to cite all syntheses, but, when appropriate, examples of relevance in medicinal chemistry or natural products will be presented. Unless otherwise noted isolated yields are given.

\section{Preparation of 2-Chromanol Derivatives: General Methods}

\subsection{Reduction of dihydrocoumarins by aluminum hydrides}

The most popular preparation of 2-chromanol $\mathbf{1}$ is probably the reduction of dihydrocoumarin, which is commercially available. Lactones can be partially reduced to lactols with the participation of a single hydride. Several aluminum hydrides are reported to accomplish such reduction. ${ }^{5}$ We report in Scheme 1 examples of reduction of dihydrocoumarin 2 to 2-chromanol 
1. Diisobutylaluminum hydride (DIBAL, solution in toluene or hexane) is usually the reagent of choice. It can be used with several solvents (toluene, THF, $\mathrm{CH}_{2} \mathrm{Cl}_{2}$ ) but requires low temperature, usually $-78{ }^{\circ} \mathrm{C}$, and inert atmosphere. High yields $(>80 \%)$ are frequently reported. ${ }^{6-8}$ The reducing power of aluminum hydrides is modified by the introduction of alkoxy groups. In this way, $(t-\mathrm{BuO})_{3} \mathrm{HAlLi}$ in THF is also used with high yields. ${ }^{9,10}$ The simple addition of one equivalent of absolute ethanol to a sodium bis[2-methoxyethoxy]aluminum hydride solution (SMEAH or Red-Al) leads to a useful reagent for the partial reduction of lactones to lactols. ${ }^{11}$ Without the above treatment with ethanol the reaction proceeded uncontrolled and gave the lactols only in poor yields. $\gamma$-Lactones are reduced selectively at $0{ }^{\circ} \mathrm{C}$ but in the case of dihydrocoumarin a lower temperature is required $\left(-60^{\circ} \mathrm{C}\right.$ or $\left.-70{ }^{\circ} \mathrm{C}\right)$.

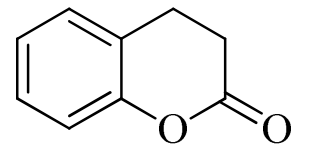

2

DIBAL, toluene $-78^{\circ} \mathrm{C}, 2 \mathrm{~h}$

$\mathrm{LiAlH}(t-\mathrm{BuO})_{3}, \mathrm{THF}$

$0{ }^{\circ} \mathrm{C}, 1.5 \mathrm{~h}$<smiles>OC1CCc2ccccc2O1</smiles>

1

$84 \%$

$90 \%$

$64 \%$ as 2,4-dinitrophenylhydrazone of

the corresponding 3-(2-hydroxyphenyl)propanal

SMEAH(benzene), $\mathrm{C}_{2} \mathrm{H}_{5} \mathrm{OH} \quad 63 \%$

toluene, $-70^{\circ} \mathrm{C}, 80 \mathrm{~min}$

\section{Scheme 1}

Other nucleophiles such as organolithium ${ }^{12-14}$ or organomagnesium ${ }^{15}$ compounds add to the carbonyl group of dihydrocoumarins to yield tertiary lactols. The Reformatsky reaction is also described. ${ }^{16,17}$ Applications are provided in sections 3.1 and 3.4.

\subsection{Titanocene-catalyzed reduction of dihydrocoumarin}

Buchwald et al. have developed a titanocene-catalyzed reduction of lactones to lactols. First, activation of titanocene di-p-chlorophenoxide $\mathbf{3}$ using PMHS (polymethylhydrosiloxane) and TBAF (tetrabutylammonium fluoride) supported on alumina generates an efficient catalyst for the hydrosilylation of the lactone. A simple aqueous work-up liberates the lactol product. ${ }^{18,19}$ Applied to dihydrocoumarin 2, this process yields 2-chromanol 1 in $87 \%$ yield (Scheme 2). 


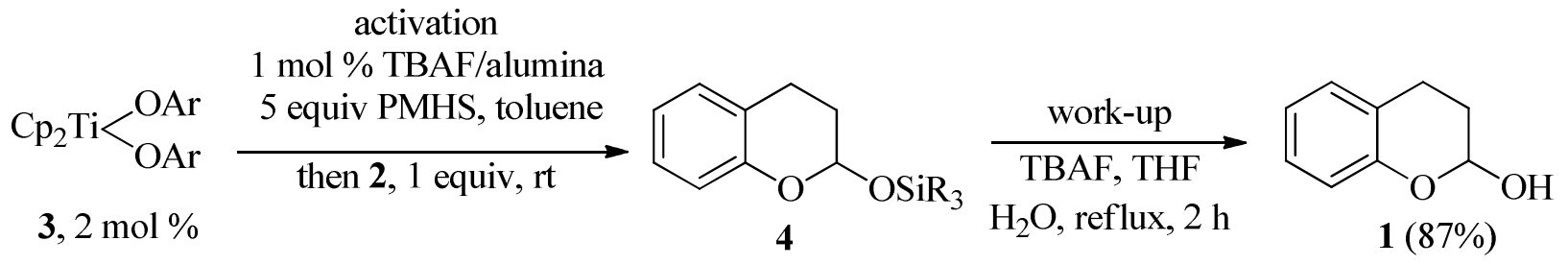

$\mathrm{OAr}=p$-chlorophenoxide

\section{Scheme 2}

\subsection{Double reduction of coumarins into 2-chromanols}

The double reduction of coumarins to 2-chromanols using $\mathrm{LiAlH}_{4}$ or $\mathrm{NaBH}_{4}$ has seldom been observed. $^{20,21}$ The double reduction of coumarins by nonracemically ligated copper hydride yields lactols in both good yields and excellent levels of stereoinduction. ${ }^{22}$ So, the combination of catalytic amounts of $[(R)$-DTBM-SEGPHOS $] \mathrm{CuH}$ in the presence of stoichiometric DEMS (diethoxymethylsilane) in toluene (or a mixture toluene/THF or dioxane) at room temperature leads to the asymmetric reduction of 4 -substituted coumarins 5 (Scheme 3). ${ }^{23}$

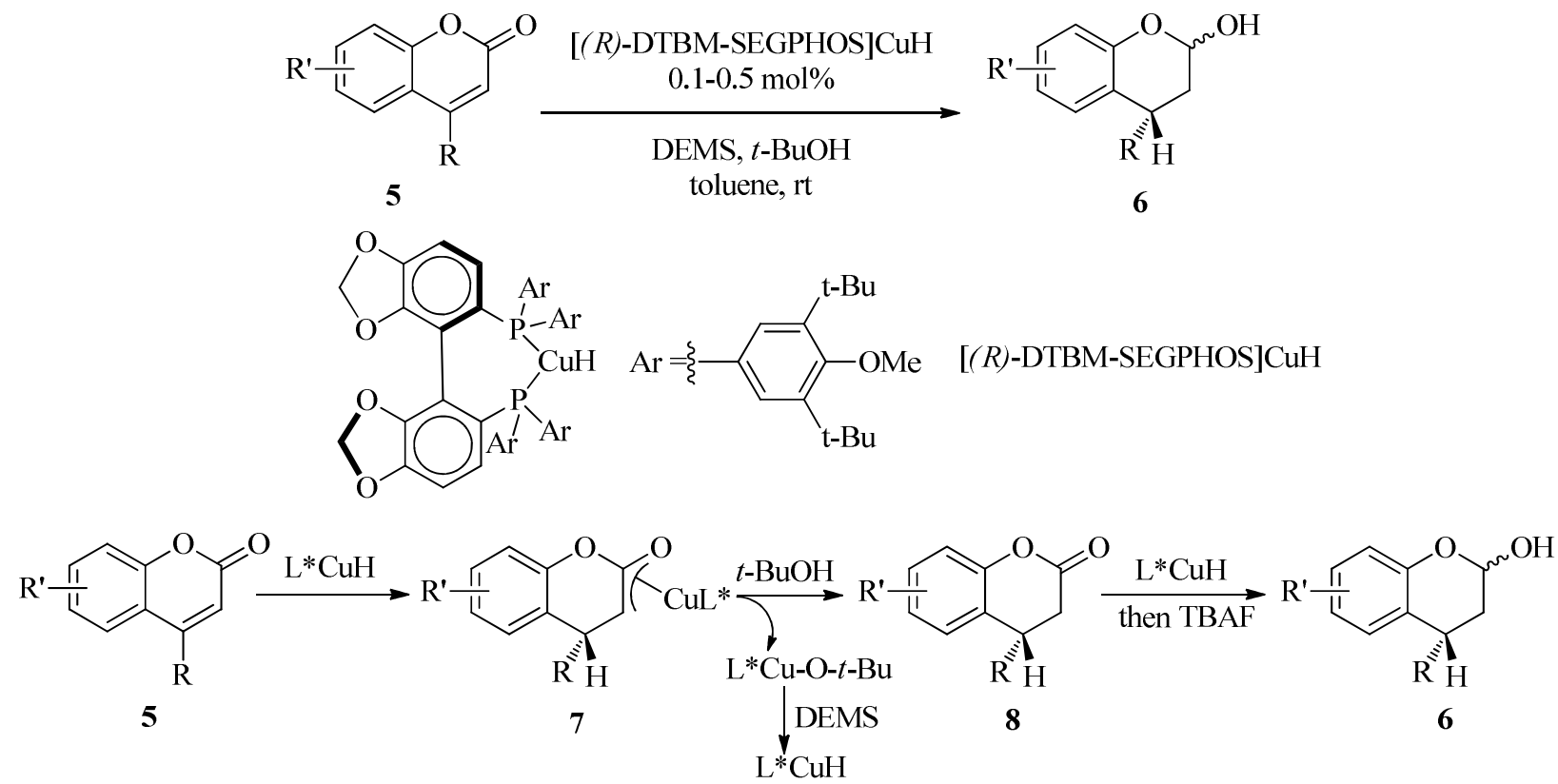

\section{Scheme 3}

This observation can be rationalized by an initial 1,4-reduction furnishing enolate 7 followed by protonation of the copper-bound enolate with $t-\mathrm{BuOH}$, thus giving dihydrocoumarin $\mathbf{8}$. Unlike typical saturated alkyl esters and lactones that are stable to $\mathrm{CuH}$, aryl lactones such as $\mathbf{8}$ are apparently activated toward 1,2-reduction. In this case, lactol $\mathbf{6}$ is obtained from initially formed 
silyl ether upon workup with TBAF (Scheme 3). Applications of this reduction are given in sections 3.3, 4.3.1 and 4.4.

\subsection{Lactols from acetals}

Hemiacetals can be prepared by the deprotection of their corresponding acetals. Most methods involve deprotection of acetals under aqueous acidic conditions. Such reactions proceed via an intermediate oxonium ion with the hydroxyl group of the hemiacetal originating from water in the reaction mixture. High yields are generally obtained as illustrated in Scheme 4 with the hydrolysis of acetal $9 .^{24}$



\section{Scheme 4}

\subsection{Intramolecular lactolization}

A well-established route for generating the hemiacetal group involves cyclization of hydroxycarbonyl derivatives. When the hydroxyl group is part of the same molecule that contains an aldehyde group, the compound exists almost entirely in the cyclic hemiacetal form. When the aldehyde group is replaced with a ketone, an equilibrium mixture can be obtained, the cyclic form being less favored.

2.5.1 Hydroformylation of protected 2-hydroxystyrene derivatives. Piccolo et al. proposed a preparation of 2-chromanol $\mathbf{1}$ by hydroformylation of protected 2-hydroxystyrenes such as $\mathbf{1 1}$ followed by deprotection of the phenol moiety and spontaneous cyclization of the initially formed 3-(2-hydroxyphenyl)propanal 12 (Scheme 5). ${ }^{25}$ 



\section{Scheme 5}

This route is convenient if the hydroformylation reaction proceeds with high regioselectivity in favor of the linear aldehyde 13 compared to 14. Several experimental conditions (catalyst, temperature, presence of ligand, pressure) were tested in order to form the linear aldehyde $\mathbf{1 3}$ in high yields. The best regioselectivity ( $>99 \%$ ) was obtained in the hydroformylation catalyzed by the $\mathrm{Pt}(\mathrm{Xantphos}) \mathrm{Cl}_{2}$ complex in toluene, however, the aldehyde yield was rather low (64\%) owing to the unsatisfactory chemoselectivity of the catalytic process. Finally, the deprotection of the phenol moiety of aldehyde $\mathbf{1 3}$ to aldehyde $\mathbf{1 2}$ followed by spontaneous cyclization afforded 2-chromanol 1 in almost quantitative yield.

2.5.2 Palladium-catalyzed conjugate addition. $\mathrm{PdCl}_{2}$ catalyzes conjugate addition of (2hydroxyaryl)mercury chlorides $\mathbf{1 5}$ with $\alpha, \beta$-unsaturated ketones $\mathbf{1 6}$ in a two-phase system. ${ }^{26}$ Intramolecular reactions may follow the conjugate addition and give 2-substituted-2-chromanols. It appears that formation of 2-chromanols is favored when $\mathrm{R}^{1}$ is other than hydrogen, when $\mathrm{R}^{2}$ is bonded to the carbonyl group through a $\mathrm{sp}^{3}$ carbon atom and when no strongly electronwithdrawing groups are present on the aromatic ring of the mercurials. Representative examples are given in Scheme 6. 


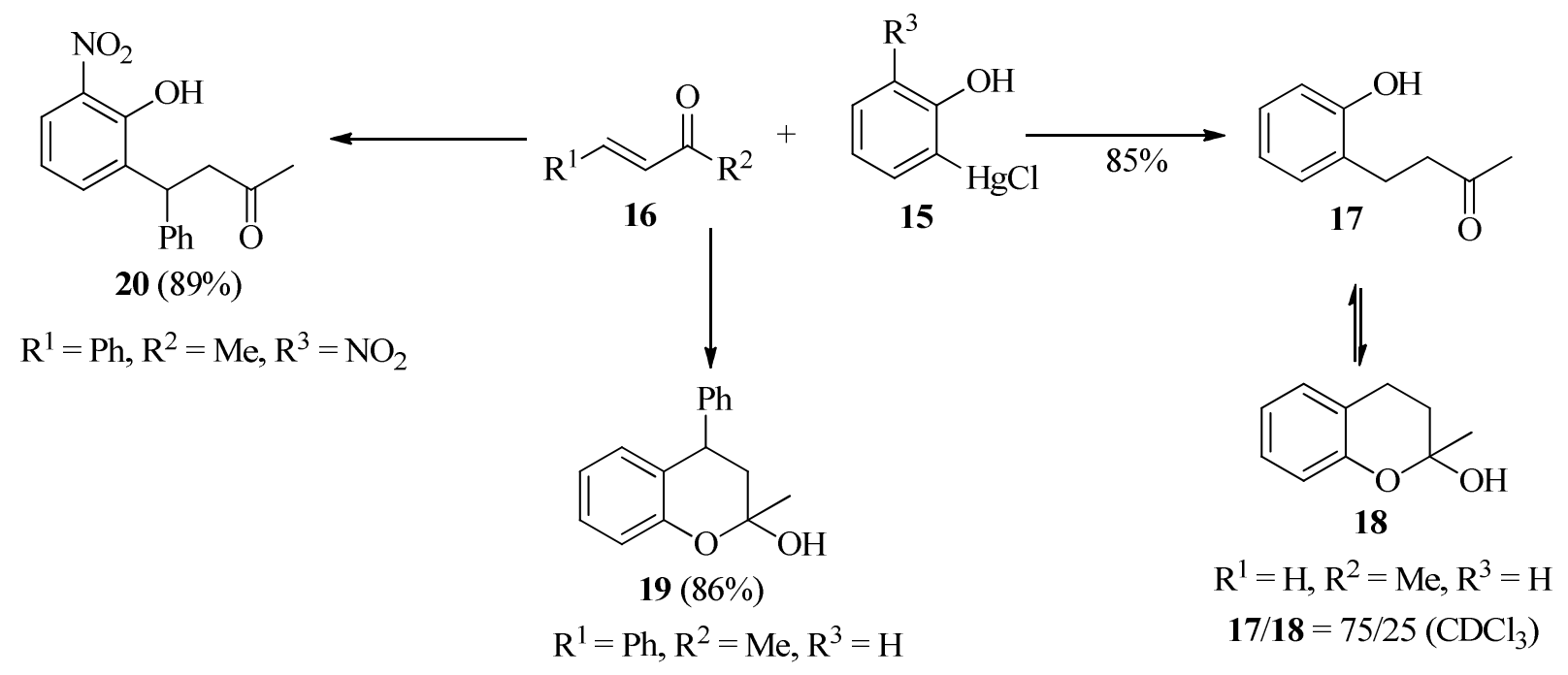

Conditions : tetrabutylammonium chloride, $\mathrm{PdCl}_{2}, \mathrm{CH}_{2} \mathrm{Cl}_{2}$ /aqueous $3 \mathrm{~N} \mathrm{HCl}, 4 \mathrm{~h}$ or $8 \mathrm{~h}, 0^{\circ} \mathrm{C}$ or rt.

\section{Scheme 6}

From the reaction of (2-hydroxyphenyl)mercury chloride with butenone $\left(\mathrm{R}^{1}=\mathrm{R}^{3}=\mathrm{H}, \mathrm{R}^{2}=\mathrm{Me}\right)$, an oil was isolated which was proved to be an equilibrium mixture of the keto form $\mathbf{1 7}$ and of the 2-chromanol form 18. The ratio $\mathbf{1 7 / 1 8}$ was $75 / 25$ in $\mathrm{CDCl}_{3}$. When $\mathrm{R}^{1}$ is replaced with a phenyl group, only the 2-chromanol form 19 was obtained. ${ }^{27}$ When the aromaric ring was substituted with an electron-withdrawing group, only the keto-phenol 20 was formed $\left(\mathrm{R}^{1}=\mathrm{Ph}, \mathrm{R}^{2}=\mathrm{Me}\right.$, $\mathrm{R}^{3}=\mathrm{NO}_{2}$ ).

\subsubsection{Asymmetric reactions of $\beta$-(2-hydroxyaryl)- $\alpha, \beta$-unsaturated ketones and $o$-hydroxy-} cinnamaldehydes with organoboronic acids. Miyaura et al. developed the enantioselective 1,4addition of arylboronic acids to $\beta$-arylenones $\mathbf{2 1}$ to give $\beta$-diaryl ketones $\mathbf{2 2}$ in the presence of a dicationic $\operatorname{Pd}(\mathrm{II})$ catalyst. $^{28}$ 2-Chromanols 23 (cis and trans isomers) are thus obtained as a mixture with 22 (Scheme 7). The yields and enantioselectivities were respectively in a range of 94-99\% and 95-99\%. The phenyl stabilized keto-phenol form displays a greater stability (22d/23d) and donor groups on the aromatic ring seem to favor the 2-chromanol form (compare 22a/23a with 22c/23c). However, the interpretation of such ratios might be far from straightforward. ${ }^{14}$ The Baeyer-Villiger oxidation of $\mathbf{2 2 d - 2 3 d}$ to 4-phenyl-2-chromanone shows the formation of the $R$-product. 
<smiles>[R]C(=O)/C=C/c1cc([R])cc([R])c1O</smiles>

21

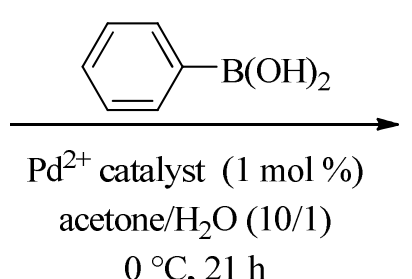

$0{ }^{\circ} \mathrm{C}, 21 \mathrm{~h}$

$$
\begin{aligned}
& \operatorname{21a} R^{1}=H, R^{2}=R^{3}=M e \\
& \operatorname{21b} R^{1}=H, R^{2}=O M e, R^{3}=M e \\
& \operatorname{21c} R^{1}=R^{2}=t \text {-Bu, } R^{3}=M e \\
& \operatorname{21d} R^{1}=R^{2}=H, R^{3}=P h
\end{aligned}
$$



$\mathrm{Ph}^{\prime} \mathrm{Ph}$

catalyst : $\left[\mathrm{Pd}(S, S\right.$-chiraphos $\left.)(\mathrm{PhCN})_{2}\right]\left(\mathrm{SbF}_{6}\right)_{2}$



22

$$
\begin{aligned}
& 99 \%(22 \mathbf{a} / \mathbf{2 3} \mathbf{a}=1 / 13,96 \% \text { ee }) \\
& 99 \%(\mathbf{2 2 b} / \mathbf{2 3 b}=1 / 16,95 \% \text { ee }) \\
& 94 \%(\mathbf{2 2} \mathbf{c} / \mathbf{2 3 c}=1 / 99) \\
& 99 \%(\mathbf{2 2 d} / \mathbf{2 3 d}=2 / 1,99 \% \text { ee })
\end{aligned}
$$

enantiomeric excess determined after conversion to 4-aryl-4H-chromene

\section{Scheme 7}



24a, 25a $\mathrm{X}=\mathrm{H}, \mathrm{R}=\mathrm{C}_{6} \mathrm{H}_{5} \mathrm{CHCH}$

24b, 25a $\mathrm{X}=3-\mathrm{MeO}, \mathrm{R}=\mathrm{C}_{6} \mathrm{H}_{5} \mathrm{CHCH}$

24c, 25a $\mathrm{X}=5-\mathrm{NO}_{2}, \mathrm{R}=\mathrm{C}_{6} \mathrm{H}_{5} \mathrm{CHCH}$

24a, 25b X $=\mathrm{H}, \mathrm{R}=4-\mathrm{MeOC}_{6} \mathrm{H}_{4} \mathrm{CHCH}$

24a, 25c $X=H, R=$

$24+25 \stackrel{26}{\longrightarrow}$

28

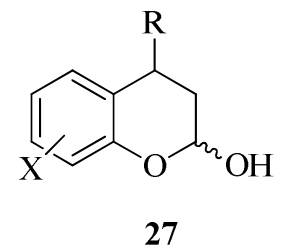

27a 83\%, 92:8 er, 3:1 dr 27b 93\%, 93:7 er, 4:1 dr 27c 81\%, 84:16 er, 4:1 $d r$ 27d 80\%, 93:7 er, 2:1 dr<smiles>CN1C(=O)[C@@H](Cc2c[nH]c3ccccc23)NC1(C)C</smiles>

27e 90\%, 78:22 er, 5:1 dr

enantiomeric ratio determined after oxidation to the corresponding lactone

\section{Scheme 8}


The catalytic asymmetric 1,4-addition reactions of organoboronic acids 25 to $O$ hydroxycinnamaldehydes $\mathbf{2 4}$ have been established using the organocatalyst $\mathbf{2 6}$ derived from imidazolidinone. After intramolecular hemiacetalization, 2-chromanols 27 are obtained in high yields and enantioselectivities. Selected examples are given in Scheme 8. The mechanism involves a transient iminium ion $\mathbf{2 8}$, the arylvinylboronic acid is activated by the phenol group and able to perform a 1,4-addition to give $29 .^{29,30}$ The regioselective control of 1,2- versus 1,4 addition in this reaction has also been investigated. ${ }^{31}$

2.5.4 Asymmetric reactions of $(E)$-2-(2-nitrovinyl)phenols with carbonyl compounds. Chiral secondary amines catalyze asymmetric tandem Michael addition-hemiacetalization between aliphatic aldehydes 31 and (E)-2-(2-nitrovinyl)phenols 30 to give 2-chromanols 32. This cascade is initiated by an enamine-mediated Michael addition to the electron-deficient alkene, followed by the intramolecular hemiacetalization. This organocatalytic reaction has been developed by several authors with catalyst, solvent and additive screenings ${ }^{32-35}$ and extended to propanone ${ }^{36}$ or $\beta$-keto esters. ${ }^{37}$ High yields and enantiomeric excess are obtained. Selected examples are given in Scheme 9. ${ }^{35}$



30

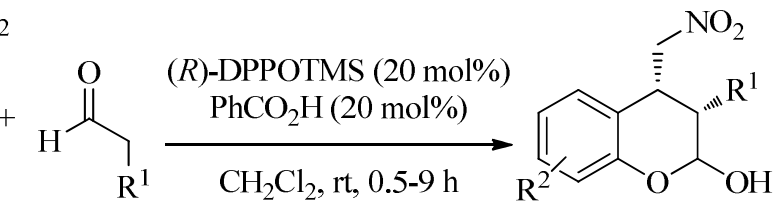

31

32<smiles>COC(c1ccccc1)(c1ccccc1)c1ccccc1</smiles>

$(R)$-DPPOTMS 31a-30a $\mathrm{R}^{1}=\mathrm{Me}, \mathrm{R}^{2}=6-\mathrm{OMe}$

31a-30b $\mathrm{R}^{1}=\mathrm{Me}, \mathrm{R}^{2}=4-\mathrm{Cl}$

31b-30a $\mathrm{R}^{1}=\mathrm{Bn}, \mathrm{R}^{2}=6-\mathrm{OMe}$

31c-30a $\mathrm{R}^{1}=n-\mathrm{Bu}, \mathrm{R}^{2}=6-\mathrm{OMe}$ 32a $95 \%, 99 \%$ ee, $93 \%$ de 32b $96 \%,>99 \%$ ee, $>99 \%$ de $e e$ and de determined after oxidation 32c $93 \%, 99 \%$ ee, $83 \%$ de 32d $95 \%, 90 \%$ ee, $83 \%$ de

\section{Scheme 9}

\section{Reactions of the Cyclic Form of 2-Chromanol Derivatives}

2-Chromanol derivatives exist in the form of two isomers: the open chain carbonyl compound and the hemiacetal cyclic form. Because these are rapidly equilibrated, we can divide the reactions of 2-chromanol derivatives in two groups, those occurring on the linear forms and those adopting the cyclic forms.

In sections 3 and 4, alkyl substituted 2-chromanols are available from catalytic hydrogenation of the double bond of the corresponding coumarins followed by reduction of the lactone group (Scheme 10). ${ }^{8,10,38-40}$ The Pechmann condensation of a phenol and a carboxylic acid or ester containing a $\beta$-carbonyl group in the presence of an acid has been widely used for the 
preparation of coumarins. ${ }^{41,42,43}$ For more complex 2-chromanol derivatives the preparation will be described.<smiles>[R]c1ccccc1OC(=O)C=[R]</smiles>

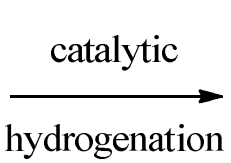<smiles></smiles>
reduction<smiles>[R]CCC(O)Oc1cc[R1]cc1CC</smiles>

\section{Scheme 10}

\subsection{Deoxygenative reduction}

In section 2.2, we described the titanocene-catalyzed reduction of dihydrocoumarin 2. Buchwald et al. combined the room-temperature protocol of lactones reduction with the deoxygenative reduction of lactols. They found that addition of the resin Amberlyst 15 (protonated form) to a solution of the lactol and triethylsilane in $\mathrm{CH}_{2} \mathrm{Cl}_{2}$ led to the rapid and clean formation of the cyclic ether. ${ }^{44}$ From dihydrocoumarin 33 this two-step procedure gives chroman $\mathbf{3 5}$ in $67 \%$ yield (Scheme 11). The deoxygenative reduction of 2-chromanols using $\mathrm{BF}_{3} \cdot \mathrm{Et}_{2} \mathrm{O}$ and $\mathrm{PhSiH}_{3}$ or $\mathrm{Et}_{3} \mathrm{SiH}$ as reducing agents is also described. ${ }^{14,34}$

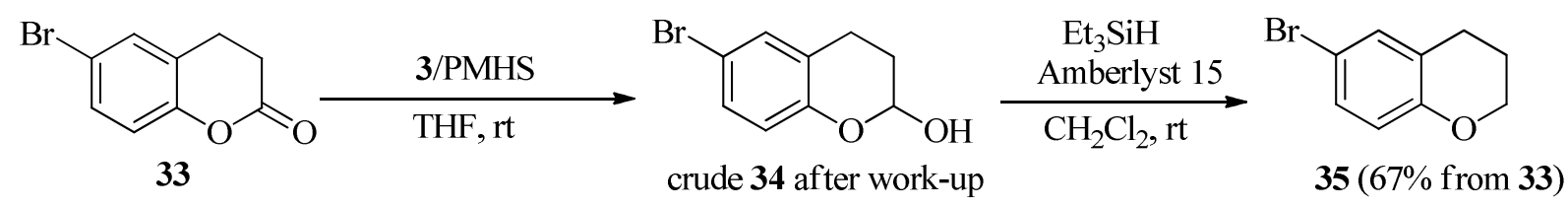

\section{Scheme 11}
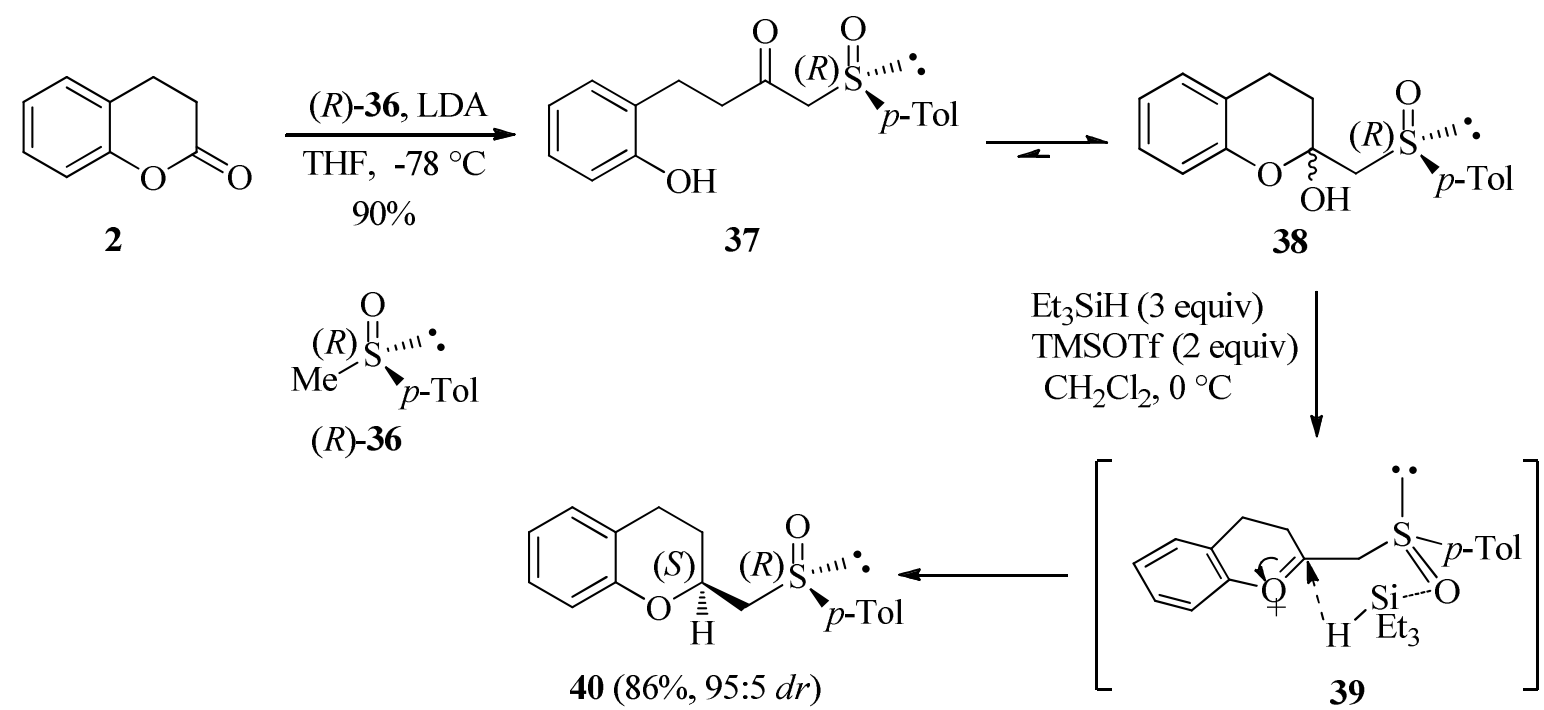

\section{Scheme 12}


Colobert et al. reported the addition of the LDA (lithium diisopropylamide) generated lithium anion of $(R)$-methyl $p$-tolylsulfoxide $(R)$-36 to dihydrocoumarin 2 . Product 37 was then isolated, in $90 \%$ yield, as an equilibrium mixture with cyclic hemiacetal $38 .{ }^{12}$ When this mixture was treated sequentially with $\mathrm{Et}_{3} \mathrm{SiH}$ and TMSOTf (trimethylsilyl trifluoromethanesulfonate) at 0 ${ }^{\circ} \mathrm{C}$, a stereoselective reductive deoxygenation process took place. Chroman $\mathbf{4 0}$ was formed in $86 \%$ yield and with an excellent 95:5 diastereoisomeric ratio (Scheme 12).

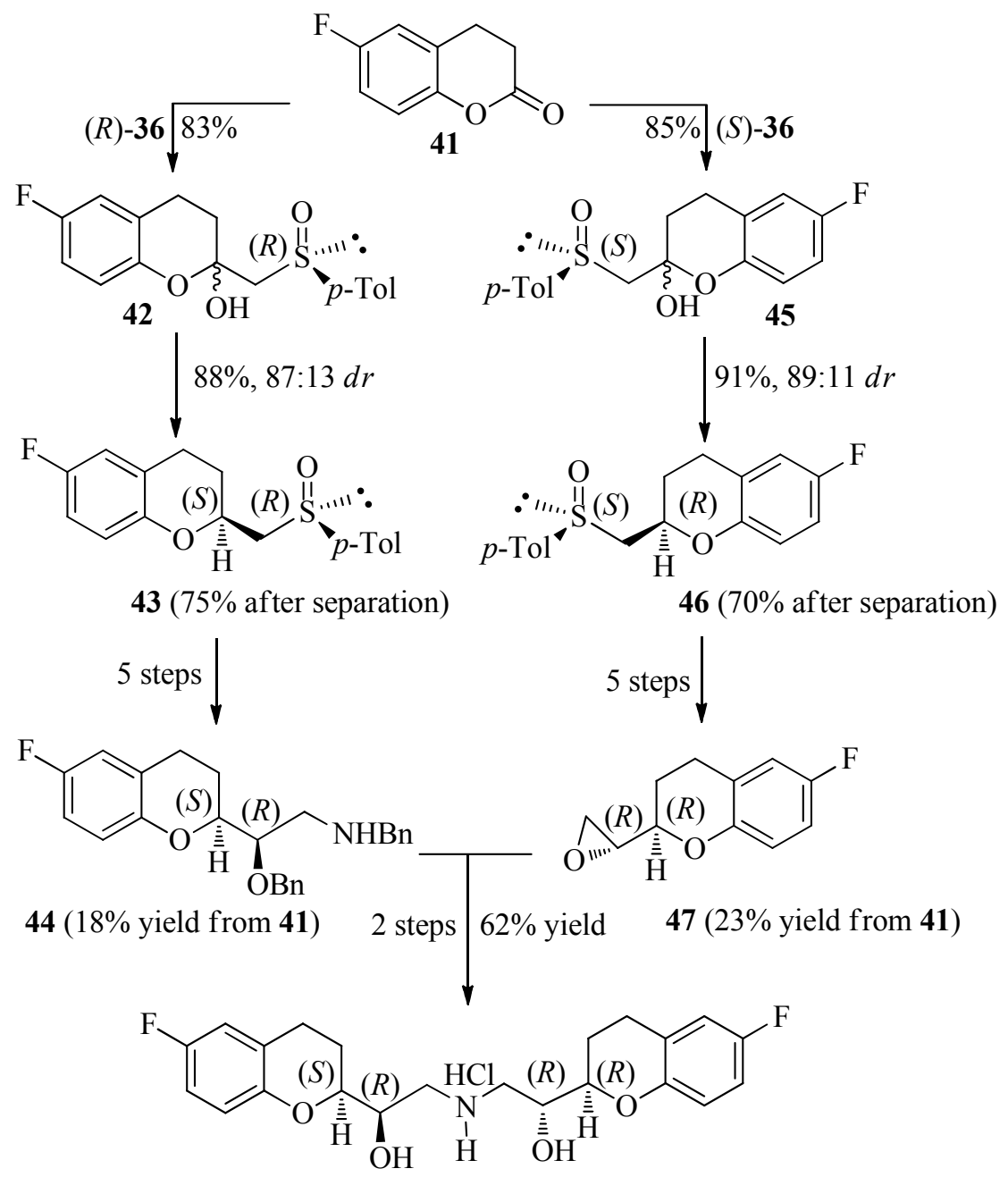

$(S, R, R, R)$-nebivolol.HCl 48 (>99\% ee)

\section{Scheme 13}

The mechanistic pathway proposed in Scheme 12 involves the initial formation of an oxocarbenium ion 39 after ionic cleavage of the $\mathrm{C}-\mathrm{OH}$ bond by activation with TMSOTf. After coordination of the silane to the sulfinyl oxygen of 39, the attack of the hydride mainly occurred from the lower face (Re-face) of the dihydrobenzopyran unit. This attack occurs in the preferred six-membered chair-like transition state showing the most favorable equatorial situation of the 
bulky $p$-tolyl substituent of the sulfoxide. Starting from this sequence applied to 6-fluoro-2chromanone 41, the authors proposed a convergent synthesis of the $(S, R, R, R)$-enantiomer of the antihypertensive drug nebivolol hydrochloride 48 (Scheme 13).

\subsection{Elimination}

Dehydration of 2-chromanol derivatives provides an access to $4 H$-chromenes. Dehydration occurs by heating with $p$-TSA (paratoluenesulfonic acid), ${ }^{15,45}$ oxalic acid ${ }^{46}$ or copper sulfate. ${ }^{47}$ Dehydration is also mediated by $\mathrm{P}_{2} \mathrm{O}_{5}$ in $\mathrm{CH}_{2} \mathrm{Cl}_{2}$ at $0{ }^{\circ} \mathrm{C}^{34}$ Another way entails esterification of $\mathbf{1}$ or 49 with acetic anhydride followed by pyrolysis of the resulting acetates 50a-b. Further, hydroboration of $4 H$-chromenes 51a-b yields 3 -chromanols 52a-b (Scheme 14). ${ }^{10,47,48}$ However, 3-chromanols 52a-b are available respectively from direct hydroboration of coumarin (12\% yield) and 4,7-dimethylcoumarin (49\% yield). ${ }^{10}$

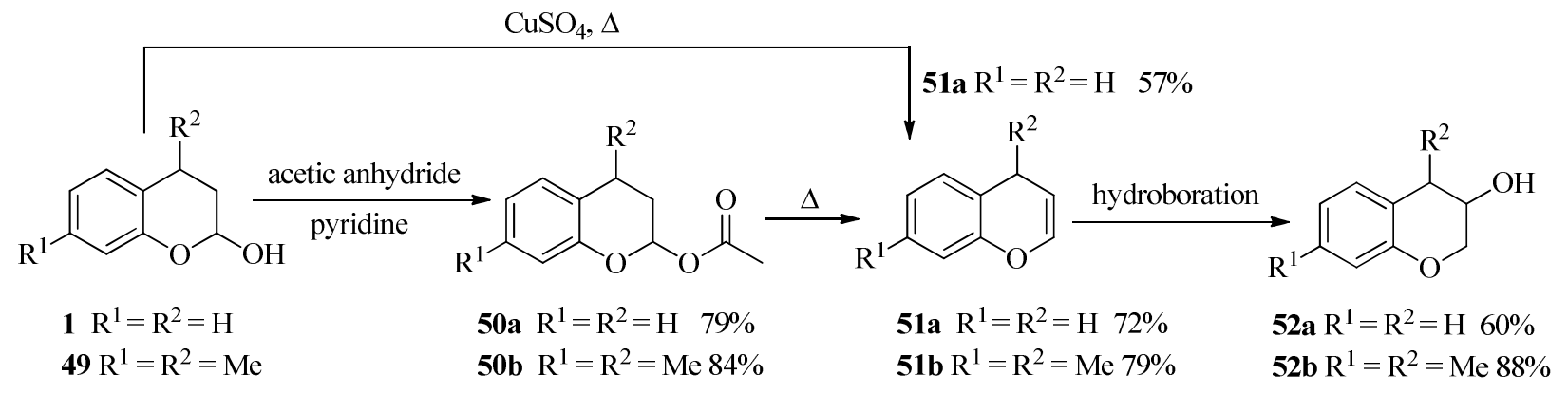

\section{Scheme 14}

Dehydration of 2-chromanol derivatives displays various synthetic applications. ${ }^{28,49,50}$ The 6methoxy-4H-1-benzopyran-7-ol 53, a major flavour compound of Wisteria sinensis, has been synthesized in 5 steps from 2,4,5-trimethoxybenzaldehyde 54. After selective ether cleavage of 54, subsequent Wittig olefination afforded scopoletin 56. The latter was successively hydrogenated and reduced with DIBAL. The final step was the dehydration of lactol $\mathbf{5 7}$ with anhydrous oxalic acid in boiling benzene (Scheme 15). ${ }^{7}$<smiles>COc1cc(OC)c(OC)cc1C=O</smiles>

54<smiles>COc1cc(C=O)c(O)cc1O</smiles>

$55(73 \%)$<smiles>CCCCC(=O)C(C)c1ccccc1</smiles>

$56(27 \%)$

\section{Scheme 15}


2-Chromanols obtained as described in sections 2-5-3 and 2-5-4 are easily dehydrated to $4 \mathrm{H}$ chromenes using $p$-TSA as catalyst in refluxing toluene. Starting from 32a and 23a-d, $4 H$ chromenes 58 and 59a-d are respectively formed in high yields (Scheme 16). ${ }^{28,35}$ 4-Aryl-4Hchromenes are identified as potent apoptosis inducers. ${ }^{51,52}$ Hydrogenation of the nitro group of $\mathbf{5 8}$ and protection of the amino group afforded chromene 60 or chroman 61 according to the reduction time. Compounds $\mathbf{6 0}$ and $\mathbf{6 1}$ are drug-like molecules; such structures possess potent anti-ischemic properties and are important as anti-hypertensives, blood vessel spasmolytics and potassium channel blockers. ${ }^{35}$

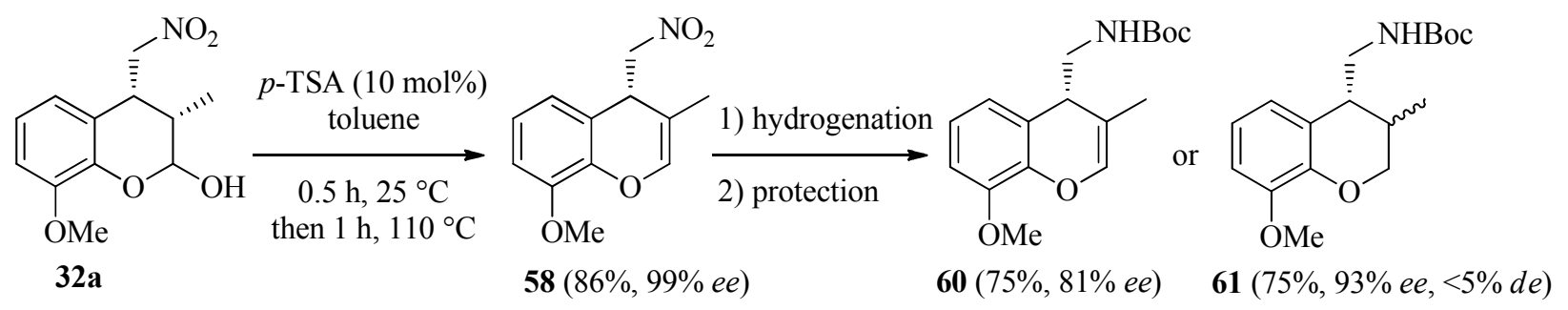

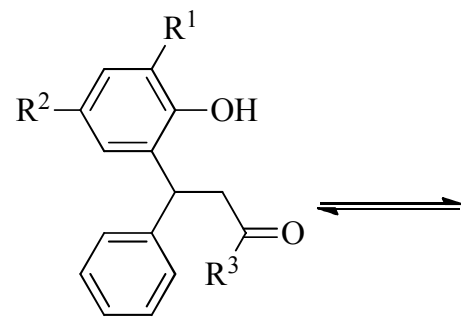

22<smiles>[R]c1cc([R])c2c(c1)C(c1ccccc1)C[C@@]([Z])(O)O2</smiles>

23

22a/23a $\mathrm{R}^{1}=\mathrm{H}, \mathrm{R}^{2}=\mathrm{R}^{3}=\mathrm{Me}$

22b/23b $\mathrm{R}^{1}=\mathrm{H}, \mathrm{R}^{2}=\mathrm{OMe}, \mathrm{R}^{3}=\mathrm{Me}$

22c/23c $\mathrm{R}^{1}=\mathrm{R}^{2}=t-\mathrm{Bu}, \mathrm{R}^{3}=\mathrm{Me}$

22d $/ 23 d R^{1}=R^{2}=H, R^{3}=P h$

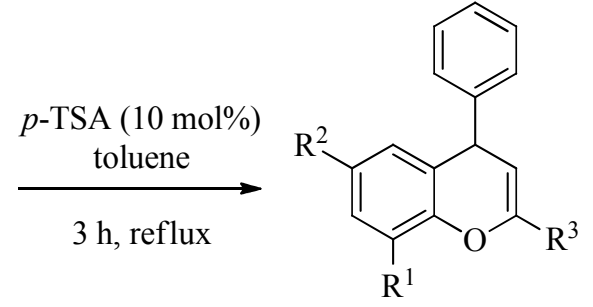

59

59a, 90\%, 96\% eе

59b, 94\%, 95\% ee

59c, $90 \%$

59d, 92\%, 99\% ee

\section{Scheme 16}

\subsection{Oxidation}

Several 2-chromanone derivatives are prepared from the corresponding 2-chromanols using $\mathrm{KMnO}_{4}$, PCC (pyridinium chlorochromate) or Jones oxidation in high yields. ${ }^{23,24,29,33-35,53-55}$ Moorthy et al. have prepared a series of dihydroisocoumarins by oxidation of the corresponding lactol using IBX (o-iodoxybenzoic acid) in a EtOAc-DMSO (9:1) mixture at reflux. With 6methyl-2-chromanol 62, a non benzylic hemiacetal, the best yields were obtained using benzene or chloroform (Scheme 17). ${ }^{35,56}$ 


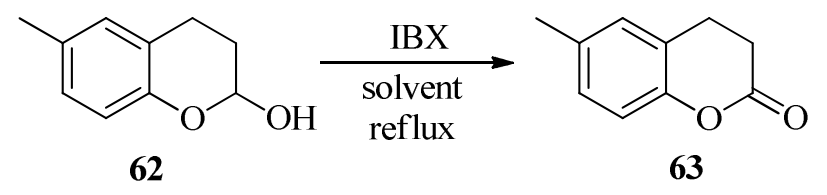

EtOAc - DMSO (9:1), 2.5-3 h, 20\%

EtOAc, $10 \mathrm{~h}, 60 \%$

$\mathrm{C}_{6} \mathrm{H}_{6}, 10 \mathrm{~h}, 80 \%$

$\mathrm{CHCl}_{3}, 10 \mathrm{~h}, 80 \%$

\section{Scheme 17}

We have mentioned in section 2.3 the double reduction of coumarins by nonracemically ligated copper hydride. ${ }^{22}$ An application leading to GPR40 agonist 64 is displayed in Scheme 18. The coumarin derivative $\mathbf{6 5}$ was prepared in 2 steps from 4-hydroxycoumarin 66 using a Suzuki coupling on the corresponding tosylate. Asymmetric reduction of 65 with catalytic [ $R$ )-DTBMSEGPHOS]CuH was followed by a PCC oxidation of the resulting lactol 67 . Lactone 68 was obtained in $86 \%$ yield from $\mathbf{6 5}$ and $97 \%$ ee. ${ }^{23}$ Saponification (LiOH) of $\mathbf{6 8}$ is known to produce 64 in an enantiopure form. ${ }^{57}$ Such strategy involving asymmetric conjugate reduction followed by oxidation was also proposed for the formal synthesis of (+)-heliannuol A, SB-217242 and SB$209670 .^{23}$
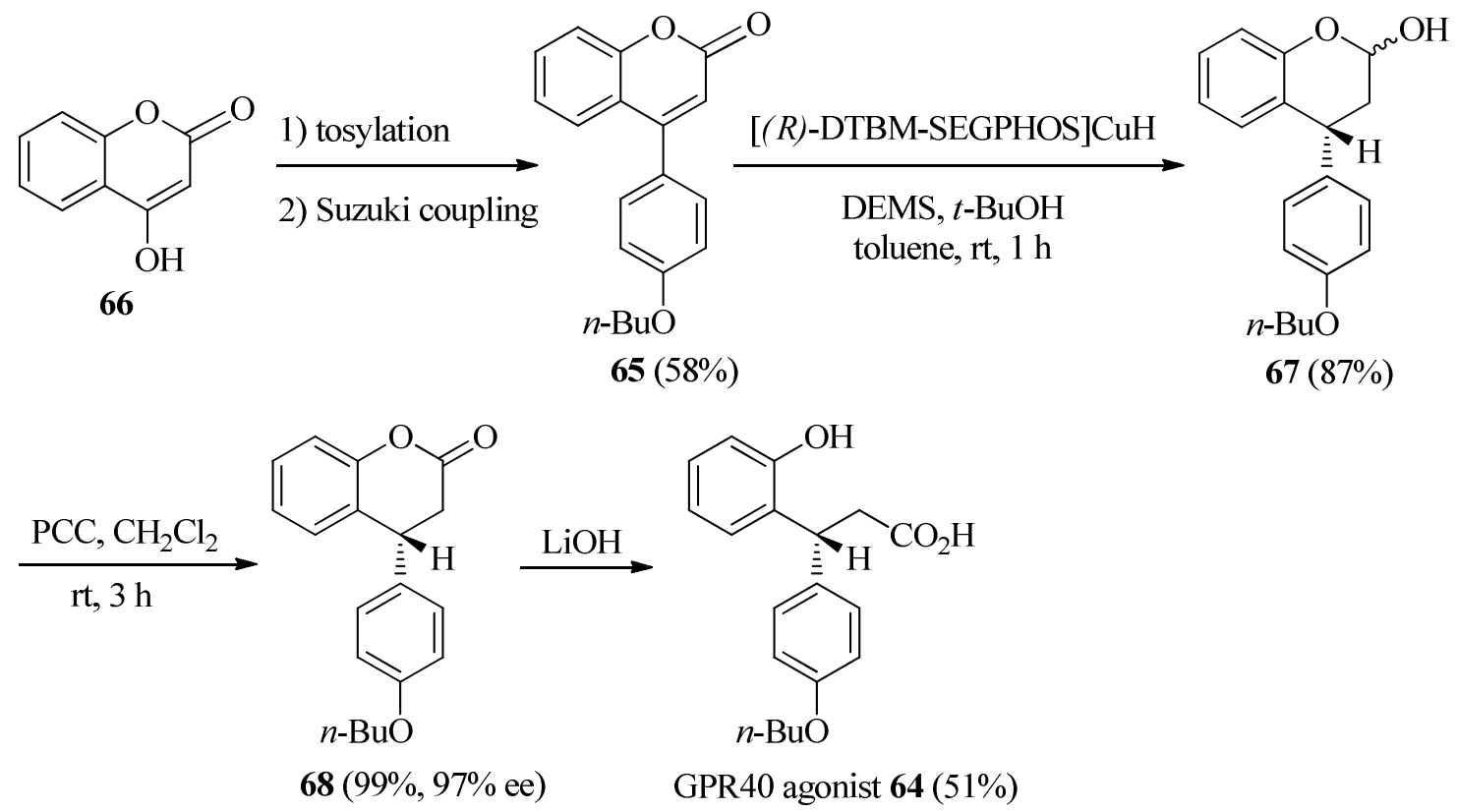

\section{Scheme 18}

\subsection{Substitution reactions. Formation of acetals}

The substitution reactions of the hydroxyl group are summarized in Scheme 19. 2-Chromanol 1 is chlorinated by $\mathrm{SOCl}_{2}$ in the presence of $\mathrm{ZnCl}_{2}$ in $80 \%$ yield. ${ }^{58}$ 2-Chromanols are converted to 
acetals when treated with an alcohol in acidic medium. ${ }^{26,35,36,59}$ So $\mathbf{1 9}$ was converted into the 2ethoxychroman derivative $\mathbf{7 0}$ through an acid-catalyzed ethanolysis in $98 \%$ yield. ${ }^{26}$ Sometimes, a different sequence, in which lactol is first treated with $\mathrm{SOCl}_{2}$ and then the alcohol is required. ${ }^{6}$ Using DAST, (diethylaminosulfur trifluoride) the $\alpha$-fluoroether $\mathbf{7 1}$ is obtained in $81 \%$ yield. $^{60,61}$ The hemiacetal function of 2-chromanol derivative 49 reacts with benzeneselenol to give the $\alpha$ phenylselenyl ether $\mathbf{7 2}$ but is also partially reduced to the chroman derivative. This drawback was overcome using the corresponding acetate $73 .{ }^{62} \alpha$-Phenylselenyl ethers provide an access to enol ethers and chemistry of $\alpha$-alkoxy anions.

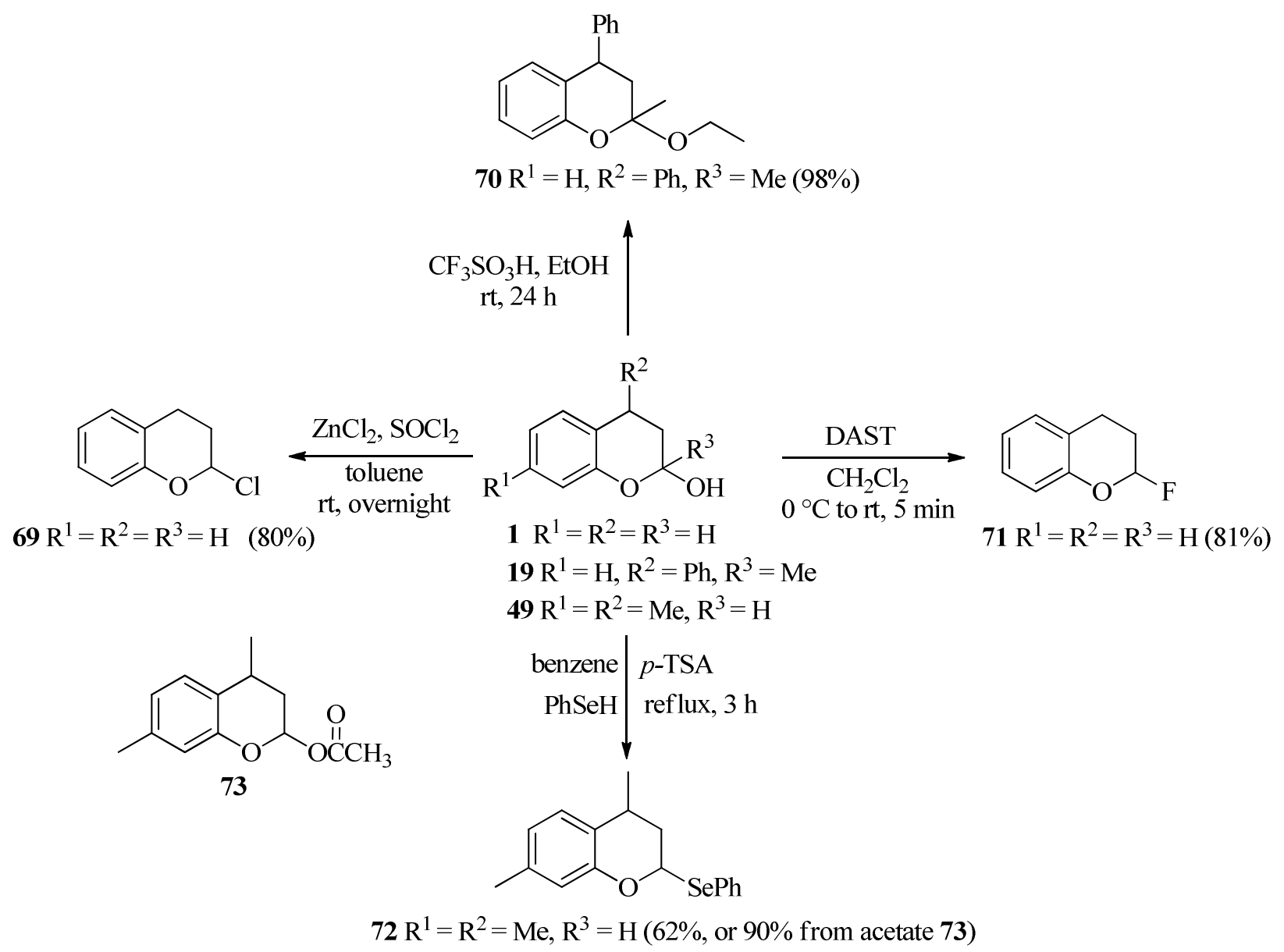

\section{Scheme 19}

The $\left(2 R, 4^{\prime} R, 8^{\prime} R\right)$ - $\alpha$-tocopherol (vitamin $\left.\mathrm{E}\right)$ is a prototypal antioxidant. Cohen et al. described the synthesis of $\left(2 R S, 4^{\prime} R, 8^{\prime} R\right)$ - $\alpha$-tocopherol as the corresponding benzyl ether 74 (Scheme 20). This form of vitamin $E$ is also called 2-ambo- $\alpha$-tocopherol and is a 1-1 mixture of epimers. $^{63}$ The acetal $\mathbf{7 5}$, derived from the reaction of methylvinylketone $\mathbf{7 6}$ with trimethylhydroquinone 77, was first treated with benzyl chloride. The acetal group was then hydrolyzed giving 2-chromanol $\mathbf{7 8}$ which appears as a key intermediate in preparations of vitamin $\mathrm{E}$ or analogues (see section 4-1). ${ }^{64-66}$ The yields displayed in Scheme 20 for the 
preparation of $\mathbf{7 8}$ are from reference 66 . Treatment of the hemiacetal $\mathbf{7 8}$ with $\mathrm{HCl}$ in ether at 0 ${ }^{\circ} \mathrm{C}$ afforded chloride 79 in $93 \%$ yield. The substitution reaction of $\mathbf{7 9}$ with the $\mathrm{C}_{16}$-side chain Grignard reagent $\mathbf{8 0}$ was studied in some detail to prevent elimination (formation of the chromene derivative). The desired reaction was favored in diethyl ether (compared to THF) and at low temperature but a moderate yield was obtained. The authors proposed the intermediacy of an oxonium ion in these substitution reactions. ${ }^{6}$

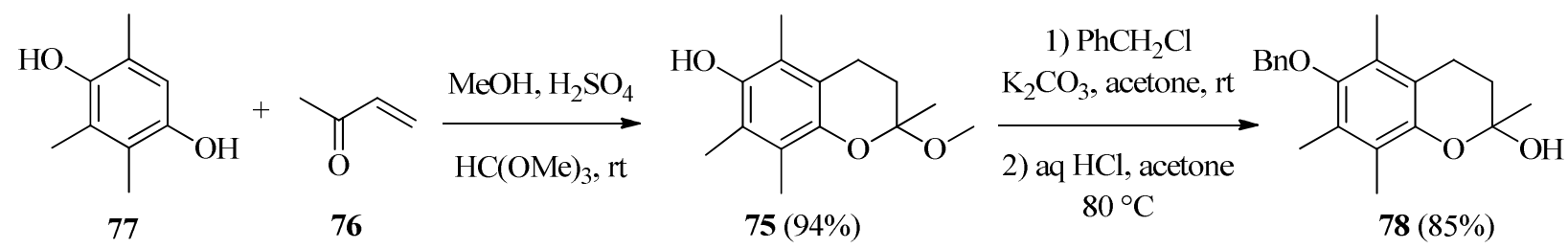
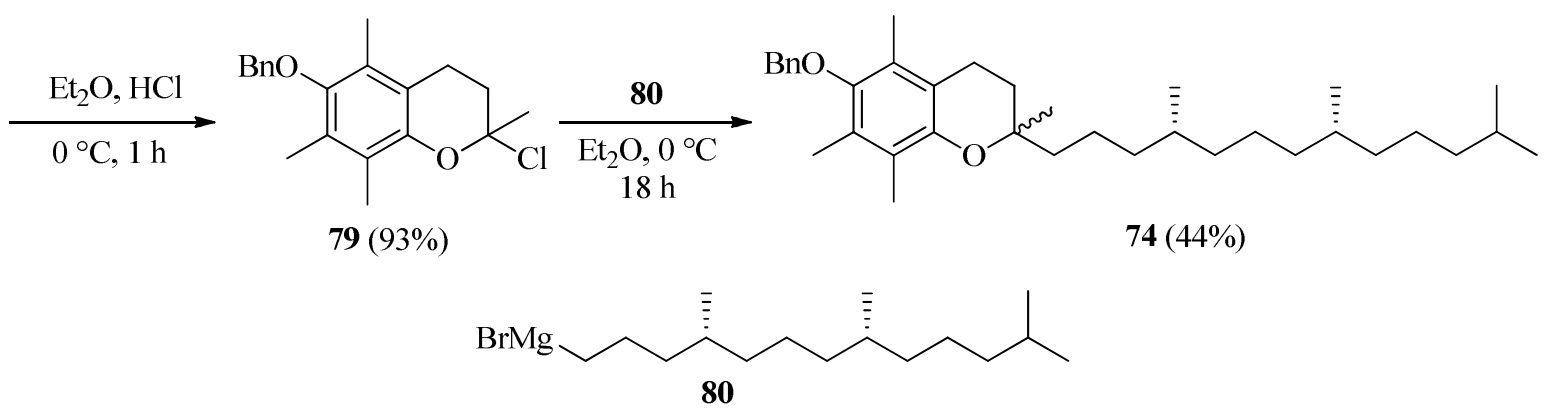

\section{Scheme 20}

Colobert et al. described an enantioselective total synthesis of the natural $\gamma$-tocopherol metabolite (S)- $\gamma$-CEHC 81 (Scheme 21). The initial Friedel-Crafts alkylation of 2,3dimethylhydroquinone $\mathbf{8 2}$ was followed by the protection of the phenol group with TBSOTf (tert-butyldimethylsilyl trifluoromethanesulfonate). Then the $\mathrm{Li}$ anion of $(S)$-methyl $p$-tolyl sulfoxide $(S)$-36 adds to the carbonyl group of the protected lactone 83. After acetalization of lactol 84 in $85 \%$ yield, the resulting 2-methoxy-3,4-dihydrobenzopyran $\mathbf{8 5}$ was submitted to the sulfoxide-directed $\mathrm{TiCl}_{4}$-promoted nucleophilic allylation using allyl trimethyl silane. The major stereoisomer 86 was obtained in $67 \%$ yield and results from the attack to the upper face of the oxocarbenium intermediate 87. $(S)$ - $\gamma$-CEHC 81 was obtained in 5 steps from 86 and $18 \%$ overall yield starting from 82. ${ }^{13}$ A similar sequence was used during the total synthesis of $\left(2 R, 4^{\prime} R S\right.$, $\left.8^{\prime} R S\right)$ - $\alpha$-tocopherol. ${ }^{67}$ 

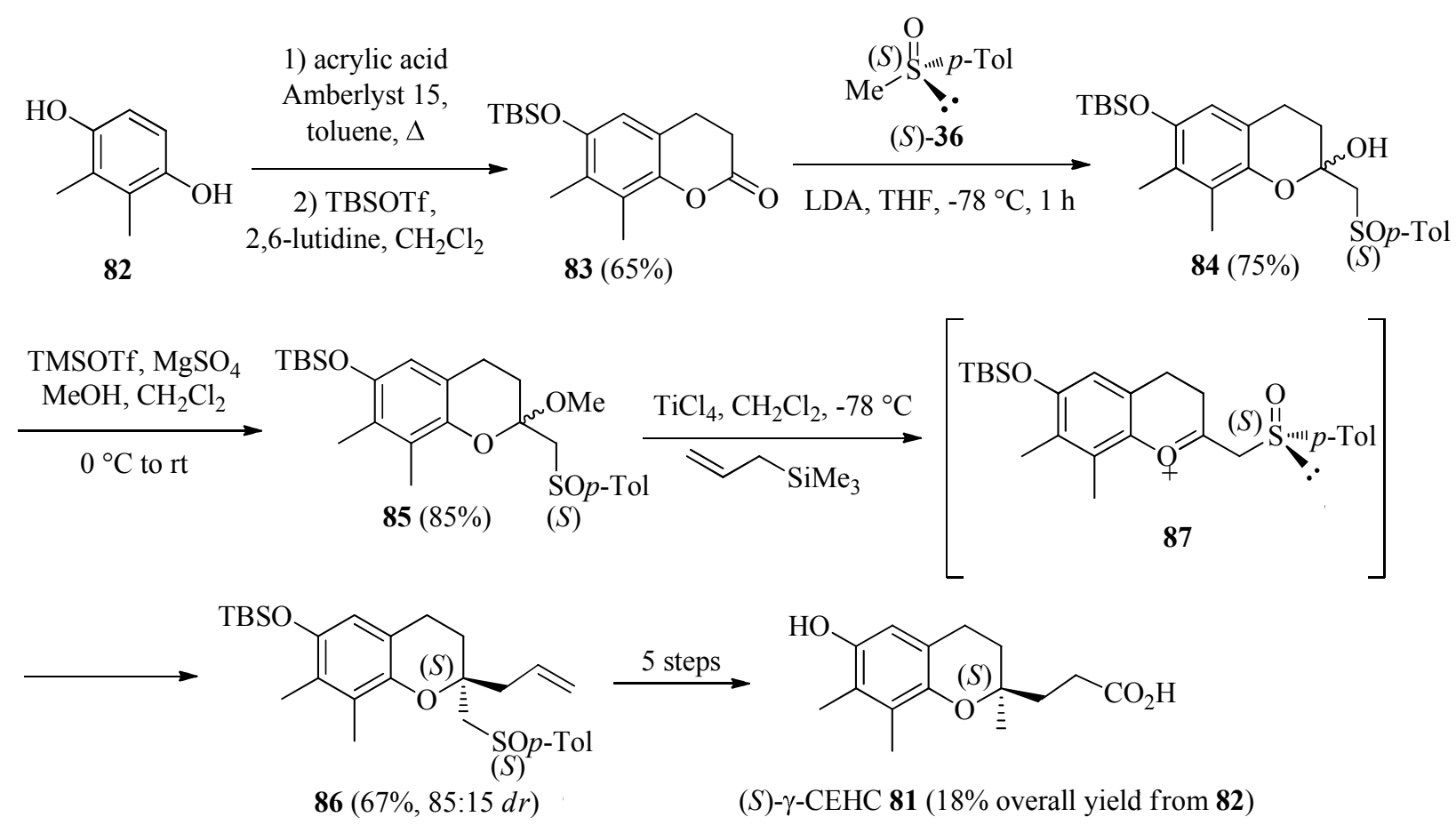

\section{Scheme 21}

\section{Reactions of the Open Form}

\subsection{Reactions of the phenol group}

The hydroxyl group in phenols undergoes several reactions of alcohols such as ether synthesis and esterification. The phenol group of the open form of 2-chromanol derivatives, after conversion to the phenoxide ion, is methylated using dimethylsulfate or methyl iodide..$^{27,36}$

Esterification of the phenol group was used for the synthesis of chiral chromans. ${ }^{40,68}$ The synthesis of chiral chromans via Pd-catalyzed intramolecular asymmetric allylic alkylation (named AAA) of phenol allyl carbonates has been extensively studied. ${ }^{69,70,40}$ Trost's group explored in detail this reaction and obtained high yields and enantioselectivities under the conditions described in Scheme 22. First, acetal $\mathbf{8 8}$ was prepared by the reaction of phenol $\mathbf{8 9}$ with methylvinylketone $\mathbf{7 6}$ (see section 3.4). The resulting acetal $\mathbf{8 8}$ was hydrolyzed with diluted $\mathrm{HCl}$ to give 2-chromanol derivative $\mathbf{9 0}$. The phenol group of the open form of $\mathbf{9 0}$ was then protected by reaction with acetyl chloride in $98 \%$ yield. Steric hindrance of the tertiary hydroxyl group of 90 seems here to favor acetylation of the phenol group. ${ }^{71}$ After a Wittig reaction, both ester groups of $\mathbf{9 2}$ were reduced to yield phenol $\mathbf{9 3}$. Esterification of $\mathbf{9 3}$ to the desired carbonate 94 was then followed by the AAA reaction to yield the chiral chroman $95 .{ }^{40}$ 


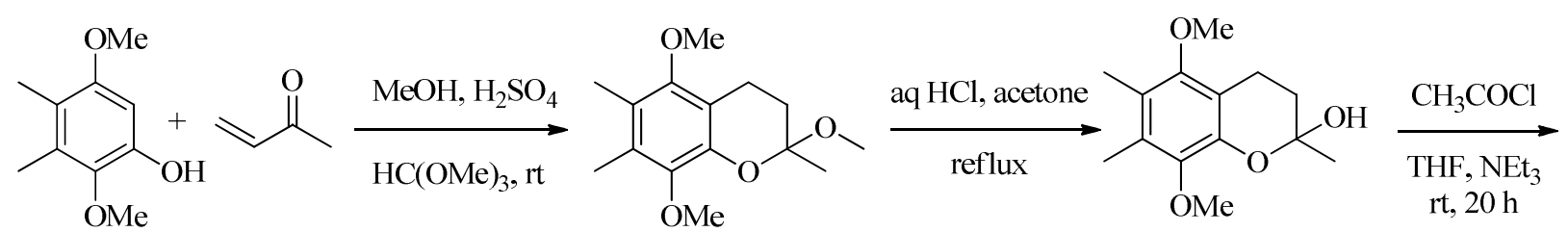

89

76

$88(70 \%)$

$90(90 \%)$<smiles>COc1c(C)c(C)c(OC)c(CCC(=O)OCC(=O)OCC(C)=CC(C)=CCc2c(OC)c(C)c(C)c(OC)c2OC(C)=O)c1CCC(C)=O</smiles>

$91(98 \%)$

$92(80 \%)$

$93(93 \%)$

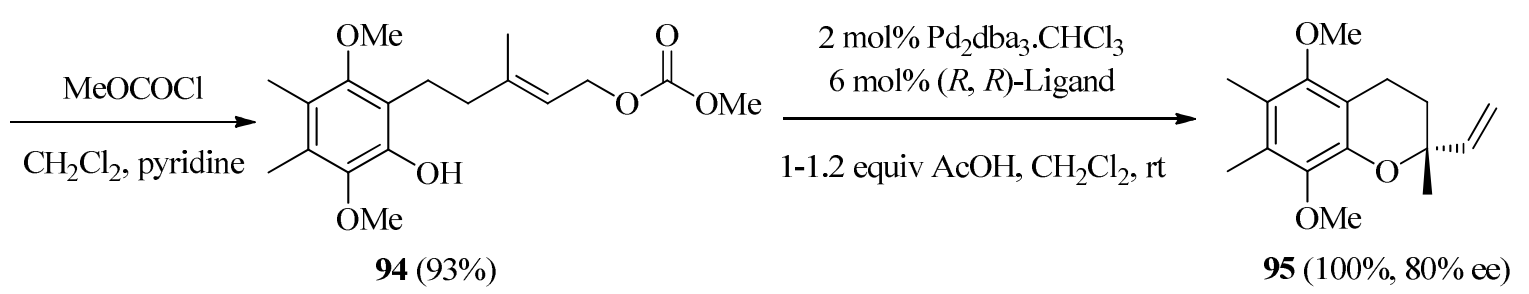<smiles>O=C(N[C@H]1CCCC[C@H]1NC(=O)c1ccccc1P)c1ccccc1P</smiles>

$\mathrm{dba}=$ dibenzylideneacetone

$(R, R)$-Ligand

\section{Scheme 22}

Tietze et al. described an enantioselective palladium-catalyzed total synthesis of vitamin E employing a domino Wacker-Heck reaction. ${ }^{66}$ The phenol group of 2-chromanol 78 (see section $3-4$ ) was esterified in $94 \%$ yield by using acetic anhydride dissolved in pyridine. Formation of the double bond using the Lombardo reagent followed by saponification afforded the desired substrate 97. The Wacker-Heck reaction of 97 and methylvinylketone $\mathbf{7 6}$ afforded the intermediate 98 in 84\% yield and 97\% ee. Vitamin E 99 was obtained in 6 steps from 98 as a 1:1 mixture together with the $\left(4^{\prime} S\right)$-epimer (Scheme 23). 
<smiles>Cc1c(C)c2c(c(C)c1OBr)CCC(C)(O)O2</smiles>

78

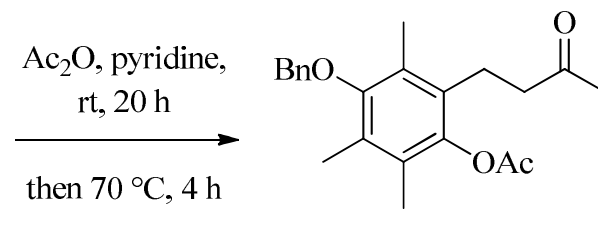

$96(94 \%)$
2) $\underset{\mathrm{MeONa}, \mathrm{MeOH}, \mathrm{rt}}{\stackrel{\mathrm{TiCl}_{4} / \mathrm{Zn}_{2} / \mathrm{CH}_{2} \mathrm{Br}_{2}}{\mathrm{CH}_{2} \mathrm{Cl}_{2}, \mathrm{rt}}}$

$97(77 \%)$<smiles>CC(=O)/C=C/C[C@@H]1CCc2c(C)c(OCC(C)C)c(C)c(C)c2O1</smiles>

Scheme 23

\subsection{Addition of carbon nucleophiles}

4.2.1 Organometallics. Transition metal catalyst. Grignard and alkyllithium reagents add to the carbonyl group to produce alcohols. The nucleophilic addition of the carbanion formed from 2-picoline to the open form of 2-chromanol 1 leads to a pyridine derivative. ${ }^{72}$

Xenognosin 100, the first identified host recognition substance for parasitic angiosperms, has been synthesized in seven steps from 7-hydroxycoumarin 101. 2-Chromanol derivative 102 was obtained in an usual way after hydogenation of the double bond, protection of the phenol group and DIBAL reduction. The complete carbon skeleton was accessible in $85 \%$ yield through the reaction of $\mathbf{1 0 2}$ with the Grignard reagent formed from the TBDMS (tert-butyldimethylsilyl) protected $p$-bromophenol. Xenognosin $\mathbf{1 0 0}$ was then obtained in 3 steps (Scheme 24). ${ }^{73}$<smiles>COc1cc(O)ccc1C/C=C/c1ccc(O)cc1/C=C/c1ccc2c(c1)OC(O)CC2</smiles>
xenognosin $100(51 \%$ from 103$)$

\section{Scheme 24}

A catalytic system of $\left[\mathrm{Ni}(\mathrm{acac})_{2}\right] / \mathrm{diene} / \mathrm{Et}_{3} \mathrm{~B}$ (acac=acetylacetonato) promotes homoallylation of aldehydes and cyclic hemiacetals. ${ }^{74,75}$ Applied to 2,3-dimethylbutadiene 104 and 2chromanol 1, phenol 105 was obtained in good yield (Scheme 25). The stereoselectivity was excellent, the reaction providing only the 1,3-anti isomer. 


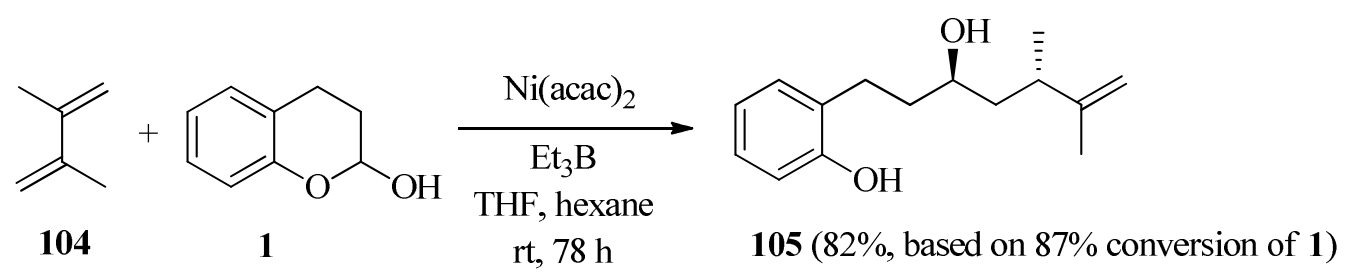

\section{Scheme 25}

4.2.2 Wittig reaction. The Wittig reaction of 2-chromanol 1 with isopropyltriphenylphosphonium bromide in the presence of KHMDS (potassium hexamethyldisilazane) gives phenol 106a in 69\% yield. With ethyl 2-(triphenylphosphoranylidene)propanoate, the $E$ isomer 106b was obtained in $92 \%$ yield (Scheme 26$)^{76}$

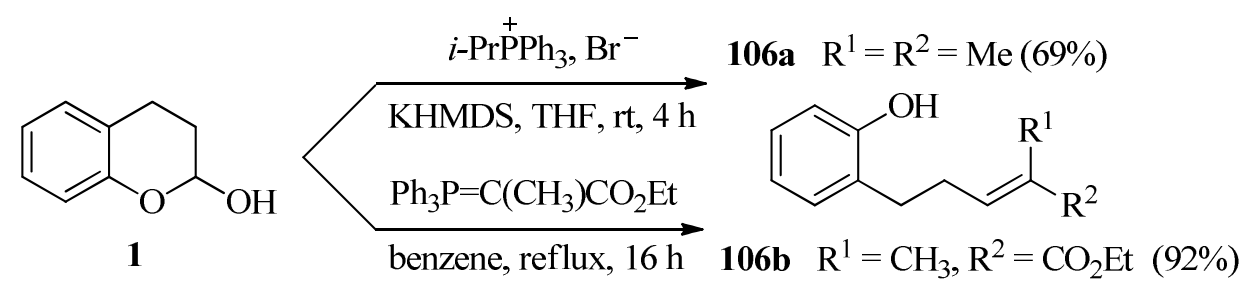

\section{Scheme 26}

The preparation of isotwistane derivatives is challenging since a few naturally occurring sesquiterpenes have the unique isotwistane framework. ${ }^{77}$ The Wittig reaction of 2-chromanol 1 with ethyl 2-(triphenylphosphoranylidene)acetate in benzene yields ester $107 \mathbf{a}^{8}$ The $E$ isomer was the major product. Isotwistane derivative 108a was obtained in $26 \%$ overall yield from 1 (Scheme 27). Even if this yield appears modest the brevity of the sequence makes this method convenient. This preparation was generalized to alkyl substituted 2-chromanols. Particularly 7ethyl-2-chromanol 109 was the precursor of coronafacic acid 110, the acidic component of coronatine, an amide which induces lesions on the leaves of Italian rye grass and hypertrophic growth of potato tuber tissue. ${ }^{38}$
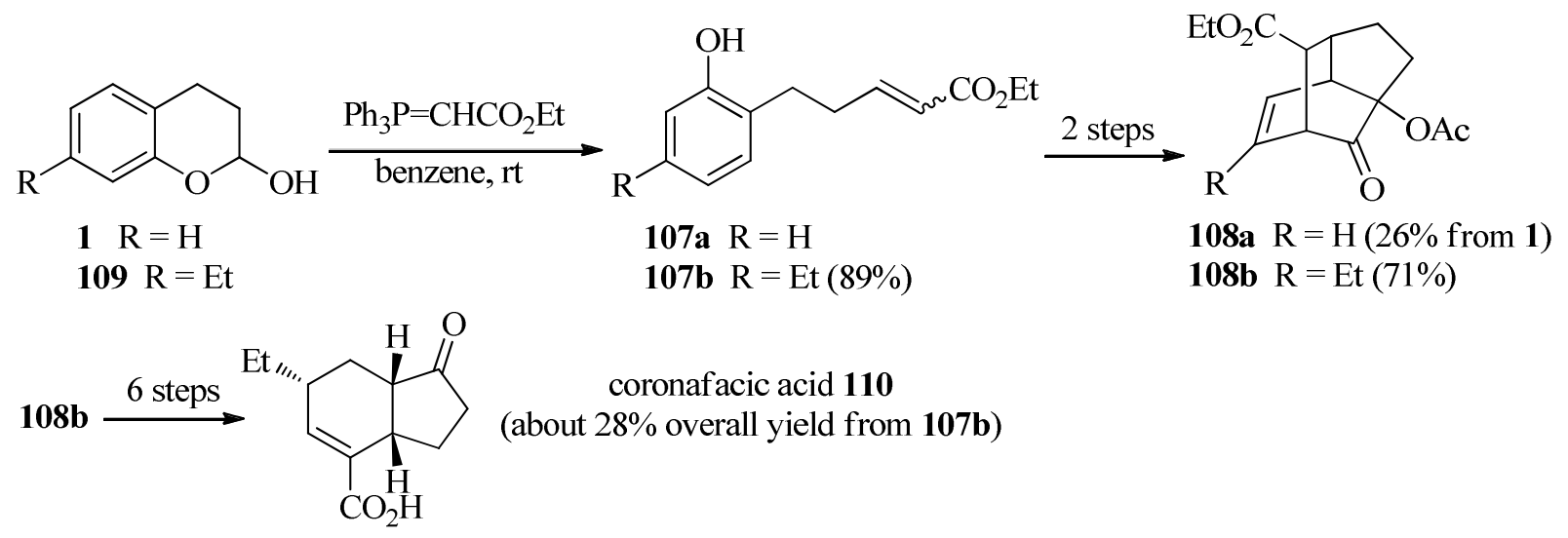

\section{Scheme 27}


Pettus et $a l$. prepared (-)-curcuphenol 111 as an intermediate in the preparation of $\alpha$-cedrene 112, $\alpha$-pipitzol 113 and sec-cedrenol 114, three members of the cedranoid family (Scheme 28). ${ }^{78}$ $\alpha$-Cedrene is an approved food preservative while sec-cedrenol has been shown to be a potent stimulant of the histamine $\mathrm{H} 3$ receptor. The latter might prove useful for the prevention and treatment of bronchial asthma, hyperlipidemia and inflammation. The enantioselective procedure begins by the addition of 2 equiv of $\mathrm{MeMgBr}$ to a flask containing the salicylaldehyde 115 and the enol ether (+)-116 (3 equiv). The resulting dianion undergoes mono carbonylation with $\mathrm{Boc}_{2} \mathrm{O}$ (di-tert-butyl dicarbonate) leading to the generation of $o$-QM 118 (o-quinone methide). ${ }^{79}$ Then a diastereoselective Diels-Alder reaction proceeds to afford the chroman ketal 119. Hydrolysis of 119 catalyzed with CSA (camphorsulfonic acid) afforded lactol 120. A Wittig reaction using $\mathrm{ClPh}_{3} \mathrm{PCH}_{2} \mathrm{OCH}_{3}$ in the presence of $n$-BuLi in THF afforded, after hydrolysis of the enol ether group, aldehyde 121 in $84 \%$ yield. Another Wittig reaction gave (-)-curcuphenol 111. $^{80}$
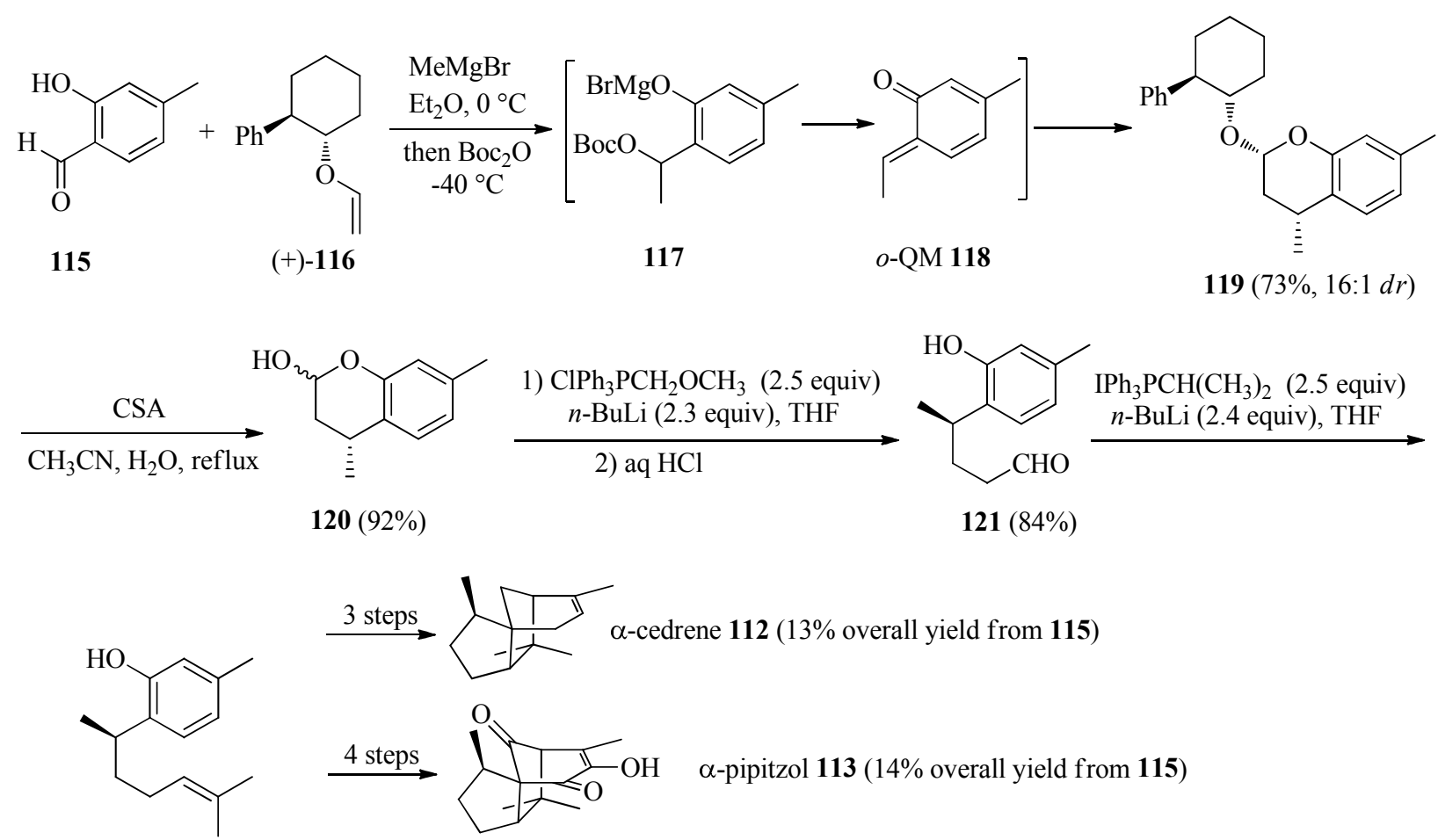

(-)-curcuphenol $111(78 \%)$

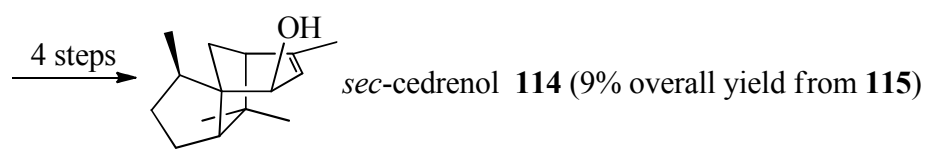

\section{Scheme 28}

The Wittig reaction of 2-chromanols affords intermediates in the preparation of chiral chromans. ${ }^{35,36}$ The esters $\mathbf{1 0 7 a}$ and 122 prepared from the Wittig reaction of 2-chromanols 1 and $\mathbf{6 2}$ are precursors in 4 steps of carbonates 123a-b (Scheme 29). Chiral chromans 124a-b were 
prepared in good yields and enantioselectivities from the asymmetric allylic alkylation of carbonates 123a-b as described in section $4.1 .^{40,69,70}$<smiles>[R]c1ccc2c(c1)CCC(O)O2</smiles>

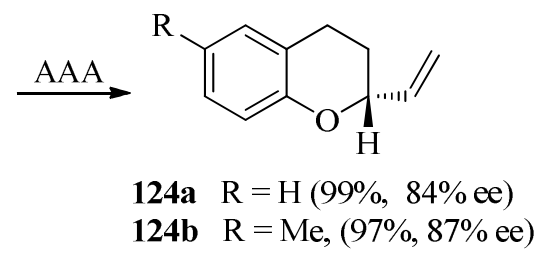

\section{Scheme 29}

Amino substituted 2-(chroman-2-yl) acetic acid esters are intermediates for producing platelet aggregation inhibitors and/or are themselves potent therapeutic agents. ${ }^{81}$ Indeed coupling of the amino group with benzoyl derivatives constitutes an additionnal step towards therapeutic agents. ${ }^{82}$ 2-Chromanol 1 appears as a precursor of amino-substituted chromans. When a Wittig reaction is performed in the presence of a base, an oxa-Michael addition follows leading to the formation of a chroman derivative. Thus, condensation of 2-chromanol 1 with ethyl 2(triphenylphosphoranylidene) acetate followed by the addition of EtONa gives acetate $\mathbf{1 2 5}$ in $89 \%$ overall yield (from dihydrocoumarin, the precursor of 2-chromanol 1). Then amino substituted 2-(chroman-2-yl)acetate 126 was obtained in 3 steps (Scheme 30). Resolving chiral intermediates to provide the desired enantiomers complete this work. ${ }^{81}$

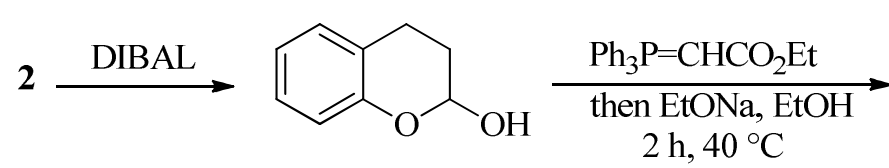

1 (crude in $\mathrm{CH}_{2} \mathrm{Cl}_{2}$ /toluene)<smiles>CCOC(=O)CC1CCc2cc(N)ccc2O1</smiles>

126 (about $86 \%$ from 125 )

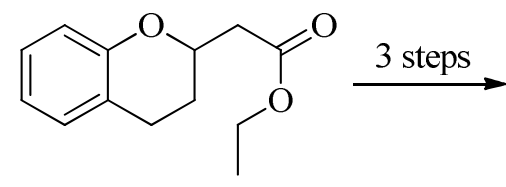

$125(89 \%$ from 2$)$

\section{Scheme 30}


Such amino-substituted chromans can also be formed via a Wittig-oxa-Michael step realized on 2-chromanols substituted at position 6 by a protected amino group or a nitro group. ${ }^{83-86}$ The drawback of these approaches is the need to perform an optical resolution during the synthesis. In this field, Merschaert et al. proposed a new asymmetric synthesis of 2-substituted chiral chromans using a chiral base in the Wittig-oxa-Michael step. ${ }^{87}$

The Wittig-oxa-Michael reaction on chromanol derivative 127 was used as a step for the synthesis of $\left(2 R, 4^{\prime} R, 8^{\prime} R\right)$ - $\alpha$-tocopherol 99 (vitamin $\mathrm{E}$ ). The Wittig-Horner reaction performed at room temperature with trimethyl phosphonoacetate was followed by heating at reflux in THF (Scheme 31 ) to yield the cyclization product $128{ }^{64}$

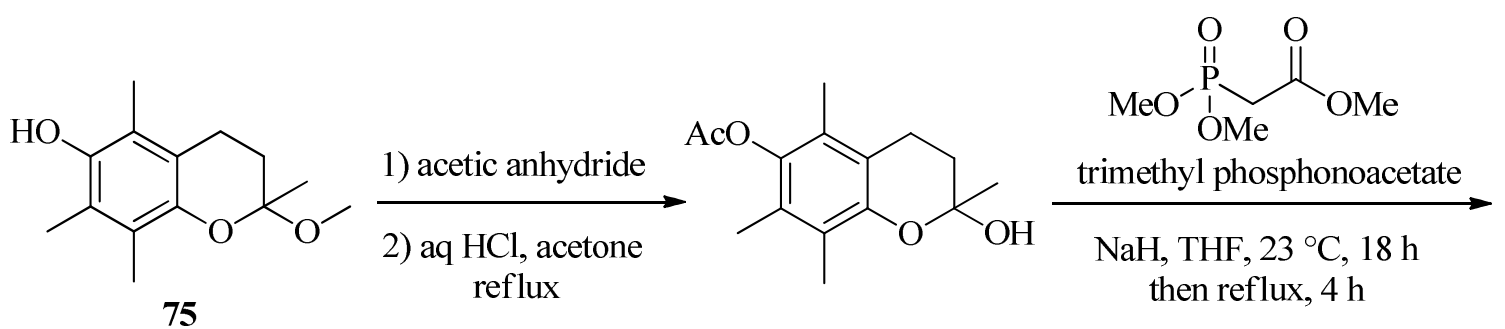

$127(90 \%$ from 77 , the precursor of $\mathbf{7 5}$,

see scheme 20)

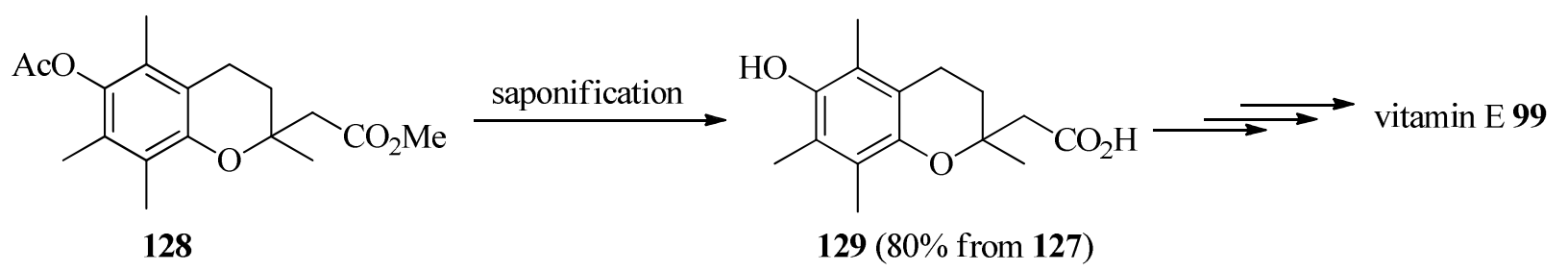

\section{Scheme 31}

4.2.3 Knoevenagel condensation. In an approach to the synthesis of trichothecene, Goldsmith et al. condensed 4,7-dimethylchromanol 49 with diethyl malonate in the presence of piperidine. Thus a tandem Knoevenagel-Michael addition takes place and the diester $\mathbf{1 3 0}$ is formed in $\mathbf{7 5 \%}$ yield (Scheme 32). ${ }^{39}$ Cheng et al. described the preparation of compounds that modulate PPAR activity. The thiazole derivative 131 provides an example (Scheme 32). The Knoevenagel condensation of 2-chromanol 1 with dimethyl malonate afforded dimethylester 132 in $47 \%$ yield. Compound 131 was prepared in 4 steps from 132, nervertheless only poor yields were obtained. $^{88}$ 


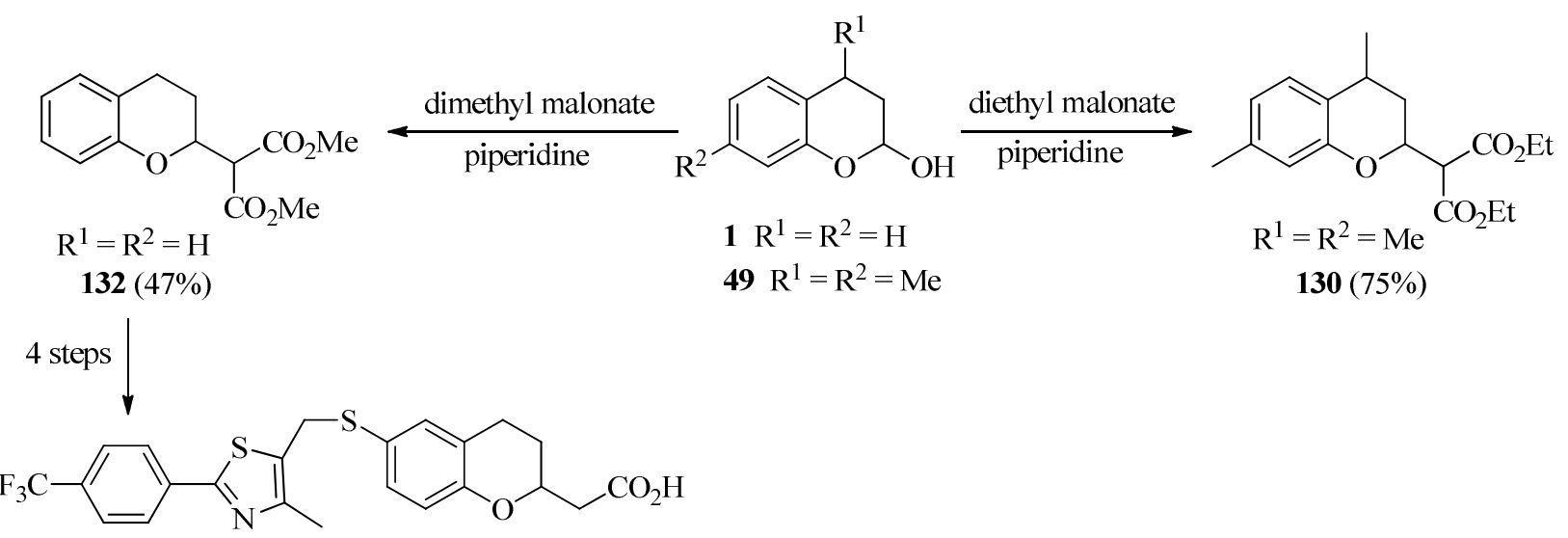

131 (about $1.5 \%$ from 132)

\section{Scheme 32}

\subsection{Addition of amines}

4.3.1 Reductive amination. The amino group adds to 2-chromanol derivatives. 2-Chromanol 1 condenses with mercaptoethylamine derivatives to form thiazolidine rings. ${ }^{9}$ A wide variety of aldehydes, ketones and lactols undergo redox amination when allowed to react with 3-pyrrolines in the presence of $\mathrm{PhCO}_{2} \mathrm{H}$ as catalyst. This reaction utilizes the inherent reducing power of 3pyrroline to perform the equivalent of a reductive amination and form $\mathrm{N}$-alkylpyrroles. Treatment of five- and six-membered lactols produces hydroxy pyrroles while redox amination of 2-chromanols 1, 133, 134 affords pyrrolyl phenols 135a-c in good yields (Scheme 33). ${ }^{89}$ Pyrrole derivatives have great importance in organic chemistry because they are present in many natural and medicinal products, and they are also very convenient precursors for biologically important compounds. ${ }^{90-92}$
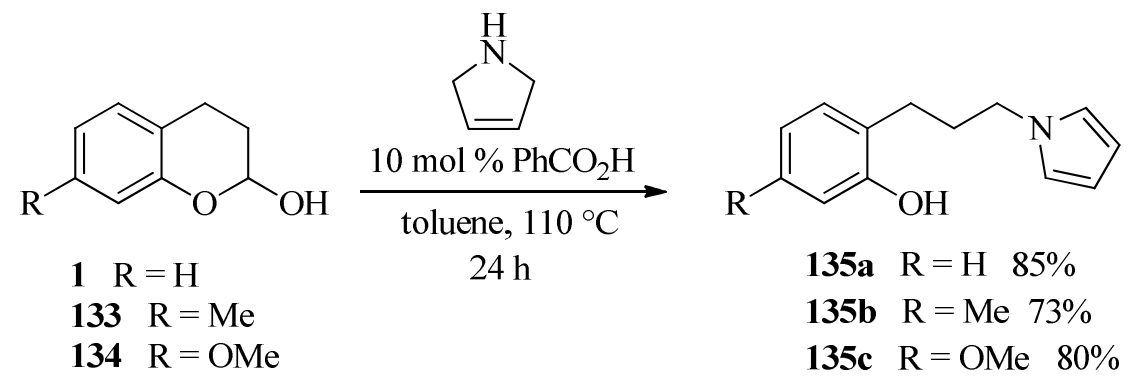

\section{Scheme 33}

The reductive amination of 4-phenyl-2-chromanol derivatives appears as a step in the preparation of several therapeutic products. 4-Phenyl-2-chromanol 136 was prepared in two steps from $o$-benzylphenol 137. Initially a dilithium species was formed and, quenching with allyl bromide, gave the racemic allyl compound 138. This was subjected to ozonolytic cleavage to 
give, after cyclization, 136. The reaction of 4-phenyl-2-chromanol 136 (mixture of diastereoisomers) with $S$-phenylethylamine in the presence of $\mathrm{NaCNBH}_{3}$ gave a 1-1 mixture of 2'hydroxy derivatives of fendiline 139a and 139b in 33\% yield (Scheme 34). ${ }^{93,94}$

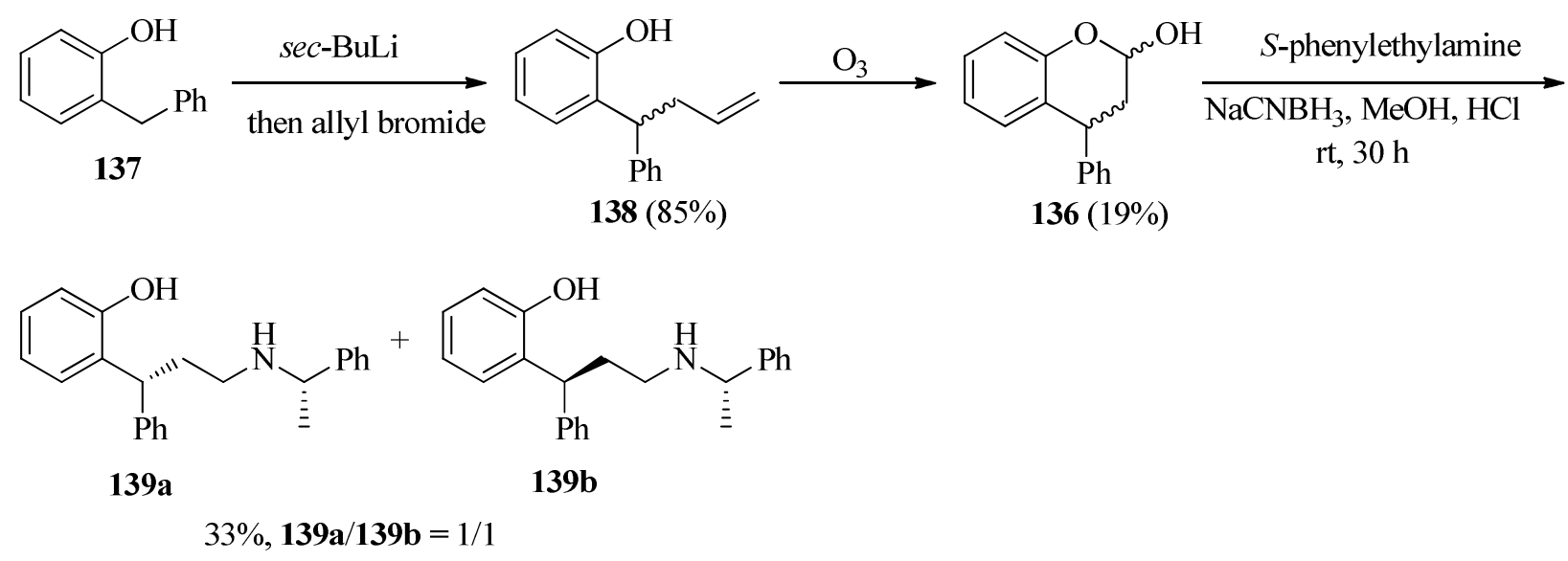

\section{Scheme 34}

Both diastereoisomers, which were cleanly isolated by column chromatography, appear as potent relaxers of isolated arteries. Such fendiline analogues also display ability to inhibit growth of human leukemia cells.

Lennon et al. prepared a set of quaternary ammonium compounds which are useful medicaments for treatment of asthma, breathing or urinary disorders, allergic rhinitis and rhinorrhea due to the cold. For this work, they used the reductive amination of 4-phenyl-2chromanol derivatives followed by quaternization of the tertiary amino group. ${ }^{95}$

The $(S)$-tolterodine $(S)$-140, which provides spasmolytic activity against urinary disorders and intestinal spams, is available after reductive amination of $(S)$-6-methyl-4-phenyl-2chromanol 141. ${ }^{96}$ The coumarin derivative 142 is formed by a Heck reaction between 2-bromo4-methylphenol 143 and methyl trans-cinnamate 144. Asymmetric hydrogenation of coumarin 142 using $\left[\mathrm{Rh}(\mathrm{COD}) \mathrm{Cl}_{2}(\mathrm{COD}=1,5\right.$-cyclooctadiene $)$ and $S, S$-Chiraphos as chiral ligand in a stainless steel autoclave under a $\mathrm{H}_{2}$ pressure gives the hydrogenated adduct 145 (84\% yield, $S / R$ =90/10). The open product 146 is formed together with 145 but cyclizes by standing or refluxing in toluene with catalytic amount of $p$-TSA. The hydrogenated lactone 145 was reduced to lactol 141 with DIBAL. The crude lactol 141 was then submitted to reductive amination conditions (Scheme 35). 

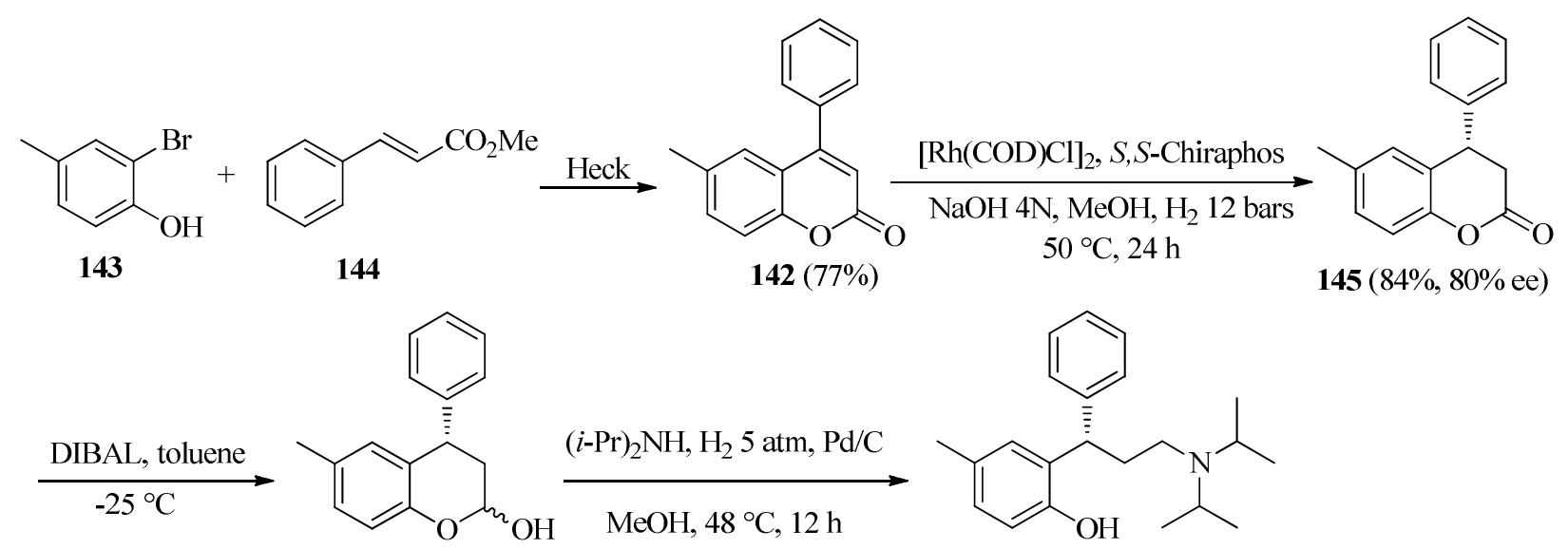

141

$(S)$-tolterodine $(S)-\mathbf{1 4 0}(73 \%$ from 145$)$<smiles>CC([C@@H](C)P(c1ccccc1)c1ccccc1)P(c1ccccc1)c1ccccc1</smiles>

$S, S$-Chiraphos<smiles>Cc1ccc(O)c([C@@H](CC(=O)O)c2ccccc2)c1</smiles>

\section{Scheme 35}

The $(R)$-tolterodine $(R)-\mathbf{1 4 0}$, a potent and competitive muscarinic receptor antagonist drug used to treat urinary incontinence and other bladder disorders, is also available from coumarin 142 alternatively prepared from a Wittig reaction. First, asymmetric conjugate addition of nonracemically ligated $\mathrm{CuH}$ (see section 2.3) on coumarin 142 yields 149. The reaction of 149 with diisopropylamine under reductive amination conditions afforded $(R)-\mathbf{1 4 0}$ in $93 \%$ yield (Scheme 36). ${ }^{23,97}$<smiles>CCC(C)C(=O)c1ccccc1</smiles>

148<smiles>Cc1ccc2oc(=O)cc(-c3ccccc3)c2c1</smiles>

$142(88 \%)$

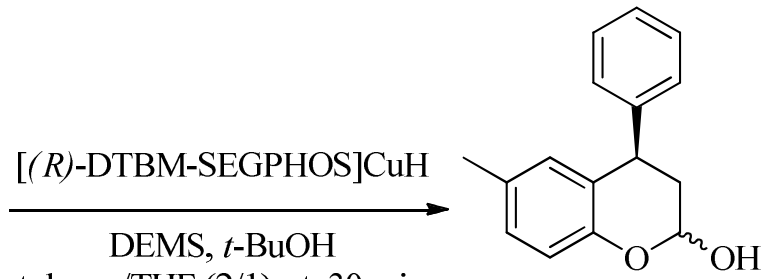

toluene/THF (2/1), rt, $30 \mathrm{~min}$
$149(99 \%, 99 \%$ ee $)$<smiles>Cc1ccc(O)c([C@H](CCN(C(=O)O[Na])C(C)C)c2ccccc2)c1</smiles>

ee determined after oxidation to the corresponding lactone

\section{Scheme 36}


4.3.2 Domino reaction. The tetrahydroquinoline moiety is an important structural feature of various natural products and pharmaceutical agents that have exhibited a broad range of biological activities. ${ }^{98,99}$ The $\mathrm{InCl}_{3}$-catalyzed reaction of aromatic amines with cyclic hemiacetals in water yields tetrahydroquinoline derivatives. ${ }^{100}$ The sequence presumably proceeds through $\mathrm{N}$-arylimine formation followed by a hetero Diels-Alder reaction. ${ }^{101}$ So the reaction of 2chromanol 1 and aniline produced [2-(o-hydroxyphenyl)]ethyl substituted tetrahydroquinolines 150a-b in $49 \%$ yield (Scheme 37).

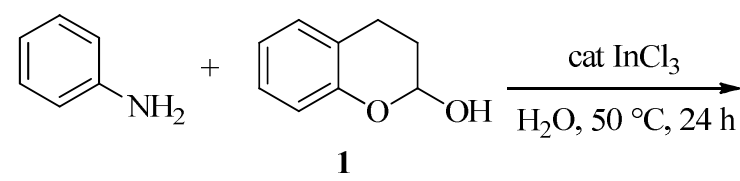

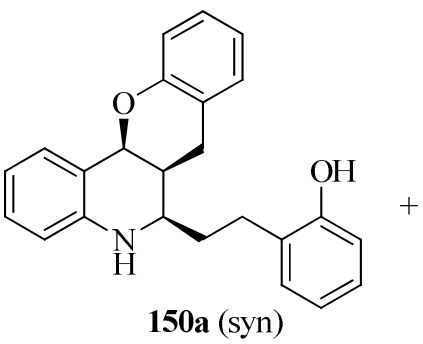

$150 a / 150 b=24 / 76$

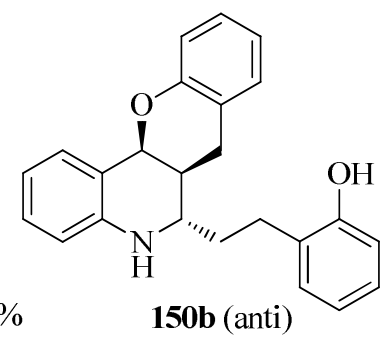

$150 b$ (anti)

\section{Scheme 37}

\subsection{Hydride reduction}

The hydride reduction of the lactol group of a 2-chromanol leads to a primary alcohol. ${ }^{35}$ This reduction was applied to one of the synthetic steps towards $(R)-4-$ methoxydalbergione $151{ }^{23}$ The latter belongs to a family of optically active quinones (dalbergiones) found in tropical woods. These natural products are known to be responsable for inducing allergic contact dermatitis. The coumarin derivative 152 was first prepared from a Wittig reaction between 2-hydroxy-4methoxybenzophenone 153 and ethyl 2-(triphenylphosphoranylidene)acetate. The asymmetric conjugate reduction of coumarin 152 (see section 2.3) yields chiral 2-chromanol derivative 154. The crude lactol 154 was then reduced with $\mathrm{LiAlH}_{4}$ to give diol 155 with an excellent yield (97\%, 2 steps) and enantiomeric excess $(99 \%$ ee). After the selective alkylation of the phenolic hydroxyl group of 155, $(R)$-4-methoxydalbergione 151 can be obtained in 4 steps as described in literature (Scheme 38). ${ }^{102}$

Pettus et $a l$. completed a synthesis of (+)- $R$-mimosifoliol 156, a natural product isolated from the rootwood of Aeschynomene mimosifolia Vatke (Leguminosae). The preparation involves 9 steps from benzaldehyde derivative $\mathbf{1 5 7}$ with a $35 \%$ overall yield. ${ }^{79,103}$ First, 157 was bisprotected in 2 steps resulting in $\mathbf{1 5 8}$. When 158 was subjected to $\mathrm{PhMgBr}$ in the presence of enol ether (-)-116, the adduct 159 was formed. This step is an enantioselective cycloaddition of the generated $o$-quinone methide (o-QM 160) with the chiral enol ether (-)-116 (see section 4-2-2). The $o-\mathrm{QM}$ results from a series of events (cascade), the first step being the nucleophilic addition of $\mathrm{PhMgBr}$ to the aldehyde group of $\mathbf{1 5 8}$. Hydrolysis of 159 catalyzed with CSA afforded 2chromanol derivative 161. The $\mathrm{LiAlH}_{4}$ reduction of lactol 161 afforded 162 in $82 \%$ yield. (+)Mimosifoliol 156 was then obtained in 4 steps from 162 (Scheme 39). 
<smiles></smiles><smiles>C=C[C@H](C1=CC(=O)C(OC)=CC1=O)c1ccccc1</smiles>

155 (97\% from 152, 99\% ee)

(R)-(+)-4-methoxydalbergione 151 (43\% from 155$)$

\section{Scheme 38}

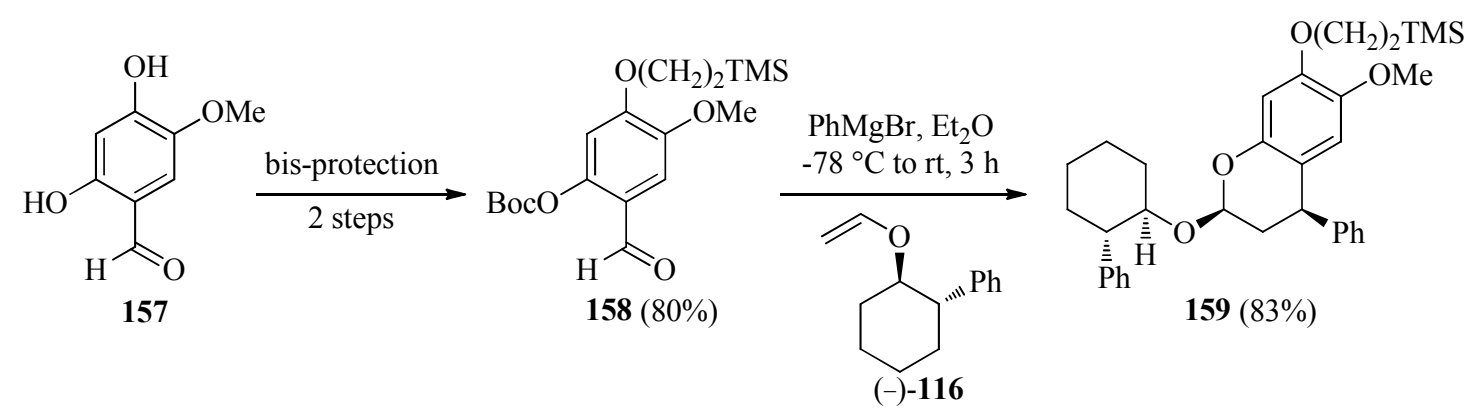

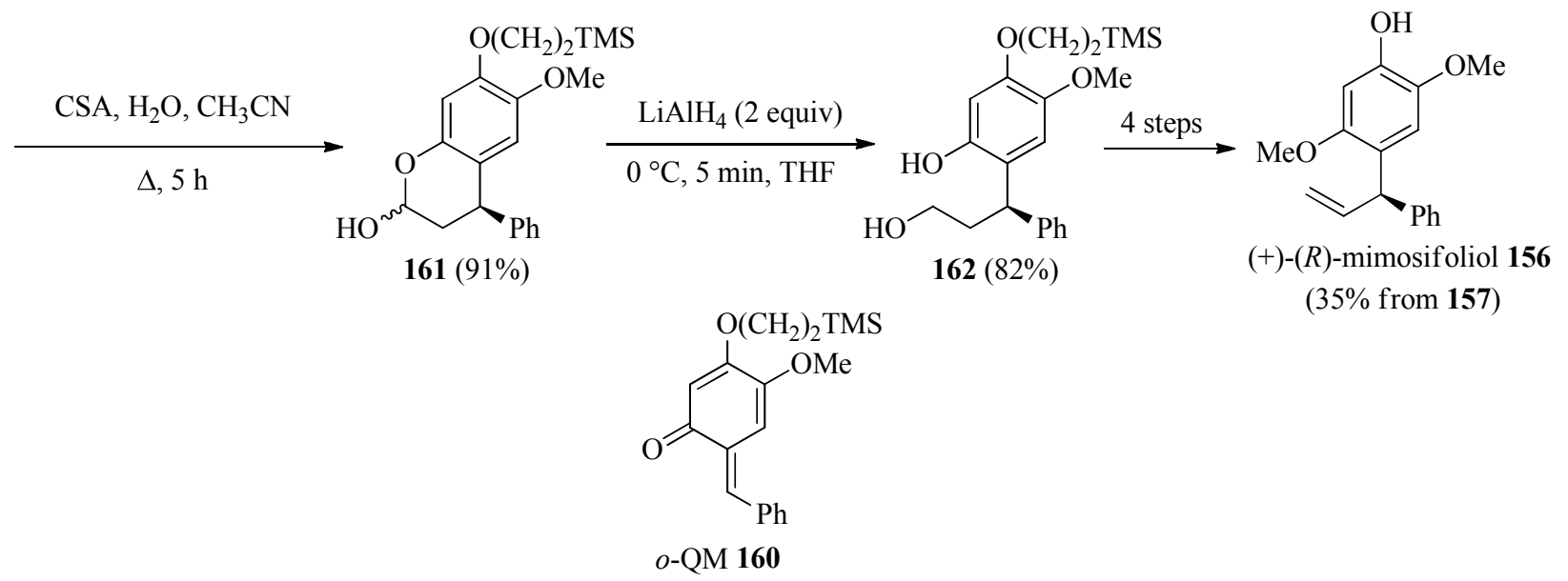

\section{Scheme 39}




\section{Conclusions}

This review focuses on the 2-chromanol moiety. Chromanol derivatives are interesting intermediates to obtain compounds with biological properties.

First of all, we described methods of preparation of 2-chromanol derivatives. If the reductions of dihydrocoumarins or coumarins have been efficiently developed, they can suffer from difficult conditions. However, deprotection of cyclic acetal can lead easily to the expected hemiacetal while intramolecular lactolization of the corresponding hydroxycarbonyl derivatives allows the use of a larger variety of substrates.

Then, reactivity of 2-chromanol derivatives has been studied. They can react on the cyclic or on the open form to yield more complex structures. Moreover, some asymmetric synthesis have been developed in order to obtain natural products or biologically active compounds with good to excellent enantiomeric excess.

\section{References}

1. Gregor, W.; Adelwöhrer, C.; Rosenau, T.; Grabner, G.; Gille, L. Ann. N.Y. Acad. Sci. 2004, $1031,344$.

2. Hsiao, G.; Lee, J.-J.; Chen, Y.-C.; Lin, J.-H.; Shen, M.-Y.; Lin, K.-H.; Chou, D.-S.; Sheu, J.-R. Biochem. Pharmacol. 2007, 73, 682.

3. Chen, J.; Li, Y.; Yang, L.-Q.; Li, Y.-Z.; Nan, Z.-B.; Gao, K. Food Chem. 2012, 131, 546.

4. Raut, C. N.; Bagul, S. M.; Janrao, R. A.; Vaidya, S. D.; Kumar, B. V. S.; Mahulikar, P. P. J. Heterocycl. Chem. 2010, 47, 582.

5. Seyden-Penne, J. Reductions by the Alumino- and Borohydrides in Organic Synthesis; $2^{\text {nd }}$ ed.; Wiley-VCH: New-York, 1997.

6. Cohen, N.; Schaer, B.; Saucy, G.; Borer, R.; Todaro, L.; Chiu, A.-M. J. Org. Chem. 1989, $54,3282$.

7. Demyttenaere, J.; Van Syngel, K.; Markusse, A. P.; Vervisch, S.; Debenedetti, S.; De Kimpe, N. Tetrahedron 2002, 58, 2163.

8. Yates, P.; Macas, T. S. Can. J. Chem. 1988, 66, 1.

9. Gandolfi, C. A.; Di Domenico, R.; Spinelli, S.; Gallico, L.; Fiocchi, L.; Lotto, A.; Menta, E.; Borghi, A.; Dalla Rosa, C.; Tognella, S. J. Med. Chem. 1995, 38, 508.

10. Clark Still Jr., W.; Goldsmith, D. J. J. Org. Chem. 1970, 35, 2282.

11. Kanazawa, R.; Tokoroyama, T. Synthesis 1976, 526.

12. Carreño, M. C.; Hernández-Torres, G.; Urbano, A.; Colobert, F. Eur. J. Org. Chem. 2008, 2035.

13. Lecea, M.; Hernández-Torres, G.; Urbano, A.; Carreño, M. C.; Colobert, F. Org. Lett. 2010, $12,580$.

14. Li, K.; Vanka, K.; Thompson, W. H.; Tunge, J. A. Org. Lett. 2006, 8, 4711.

15. Valla, C.; Baeza, A.; Menges, F.; Pfaltz, A. Synlett 2008, 3167. 
16. Cuenca, A. B.; D'Hooge, F.; Gouge, V.; Castelot-Deliencourt, G.; Oulyadi, H.; Leclerc, E.; Jubault, P.; Pannecoucke, X.; Quirion, J.-C. Synlett 2005, 2627.

17. Zoute, L.; Lemonnier, G.; Nguyen, T. M.; Quirion, J.-C.; Jubault, P. Tetrahedron Lett. 2011, 52, 2473.

18. Verdaguer, X.; Berk, S. C.; Buchwald, S. L. J. Am. Chem. Soc. 1995, 117, 12641.

19. Verdaguer, X.; Hansen, M. C.; Berk, S. C.; Buchwald, L. J. Org. Chem. 1997, 62, 8522.

20. Petkova, N. I.; Nikolova, R. D.; Bojilova, A. G.; Rodios, N. A.; Raptopoulou, C. P. Synth. Commun. 2006, 36, 509.

21. Stout, G. H.; Sears, K. D. J. Org. Chem. 1968, 33, 4185.

22. Lipshutz, B. H.; Frieman, B. A.; Unger, J. B.; Nihan, D. M. Can. J. Chem. 2005, 83, 606.

23. Gallagher, B. D.; Taft, B. R.; Lipshutz, B. H. Org. Lett. 2009, 11, 5374.

24. Panetta, J. A.; Rapoport, H. J. Org. Chem. 1982, 47, 946.

25. Botteghi, C.; Paganelli, S.; Moratti, F.; Marchetti, M.; Lazzaroni, R.; Settambolo, R.; Piccolo, O. J. Mol. Catal. A: Chem. 2003, 200, 147.

26. Cacchi, S.; Misiti, D. J. Org. Chem. 1982, 47, 2995.

27. Hall, R. H.; Howe, B. K. J. Chem. Soc. 1959, 2886.

28. Nishikata, T.; Yamamoto, Y.; Miyaura, N. Adv. Synth. Catal. 2007, 349, 1759.

29. Choi, K.-S.; Kim, S.-G. Tetrahedron Lett. 2010, 51, 5203.

30. Kim, S.-G. Tetrahedron Lett. 2008, 49, 6148.

31. Choi, K.-S.; Kim, S.-G. Synthesis 2010, 3999.

32. Enders, D.; Wang, C.; Yang, X.; Raabe, G. Adv. Synth. Catal. 2010, 352, 2869.

33. Hong, B.-C.; Kotame, P.; Liao, J.-H. Org. Biomol. Chem. 2011, 9, 382.

34. Lu, D.; Li, Y.; Gong, Y. J. Org. Chem. 2010, 75, 6900.

35. Ramachary, D. B.; Prasad, M. S.; Madhavachary, R. Org. Biomol. Chem. 2011, 9, 2715.

36. Ramachary, D. B.; Sakthidevi, R. Org. Biomol. Chem. 2010, 8, 4259.

37. Enders, D.; Urbanietz, G.; Raabe, G. Synthesis 2011, 1905.

38. Yates, P.; Bhamare, N. K.; Granger, T.; Macas, T. S. Can. J. Chem. 1993, 71, 995.

39. Goldsmith, D. J.; Helmes Jr., C. T. Synth. Commun. 1973, 3, 231.

40. Trost, B. M.; Shen, H. C.; Dong, L.; Surivet, J.-P.; Sylvain, C. J. Am. Chem. Soc. 2004, 126, 11966.

41. Fries, K.; Klostermann, W. Chem. Ber. 1906, 39, 871.

42. Bailey, G. C.; Boettner, F. J. Ind. Eng. Chem. 1921, 13, 905.

43. For other synthetic methods for coumarin derivatives, see : Valizadeh, H.; Shockravi, A. Tetrahedron Lett. 2005, 46, 3501 and references cited therein.

44. Hansen, M. C.; Verdaguer, X.; Buchwald, S. L. J. Org. Chem. 1998, 63, 2360.

45. Evans, C. M.; Kirby, A. J. J. Chem. Soc. Perkin Trans. 2 1984, 1269.

46. Evans, C. M.; Kirby, A. J. J. Chem. Soc. Perkin Trans. 2 1984, 1259.

47. Clark-Lewis, J. W.; McGarry, E. J. Aust. J. Chem 1973, 26, 819.

48. Parham, W. E.; Huestis, L. D. J. Am. Chem. Soc. 1962, 84, 813. 
49. Zacheis, D.; Dhar, A.; Lu, S.; Madler, M. M.; Klucik, J.; Brown, C. W.; Liu, S.; Clement, F.; Subramanian, S.; Weerasekare, M.; Berlin, K. D.; Gold, M. A.; Houck Jr., J. R.; Fountain, K. R.; Benbrook, D. M. J. Med. Chem. 1999, 42, 4434.

50. Liepa, A. J. Aust. J. Chem 1984, 37, 2545.

51. Sciabola, S.; Carosati, E.; Cucurull-Sanchez, L.; Baroni, M.; Mannhold, R. Bioorg. Med. Chem. 2007, 15, 6450.

52. Gao, M.; Wang, M.; Miller, K. D.; Hutchins, G. D.; Zheng, Q.-H. Appl. Radiat. Isot. 2010, 68,110 .

53. Amantini, D.; Fringuelli, F.; Pizzo, F. J. Org. Chem. 2002, 67, 7238.

54. Morton, J. G. M.; Kwon, L. D.; Freeman, J. D.; Njardarson, J. T. Synlett 2009, 23.

55. Wada, E.; Kanemasa, S.; Tsuge, O. Bull. Chem. Soc. Jpn. 1989, 62, 1198.

56. Moorthy, J. N.; Singhal, N.; Mal, P. Tetrahedron Lett. 2004, 45, 309.

57. Song, F.; Lu, S.; Gunnet, J.; Xu, J. Z.; Wines, P.; Proost, J.; Liang, Y.; Baumann, C.; Lenhard, J.; Murray, W. V.; Demarest, K. T.; Kuo, G.-H. J. Med. Chem. 2007, 50, 2807.

58. Sipilä, K.; Kansikas, J. Phosphorus, Sulfur and Silicon 2002, 117, 437.

59. Wulff, G.; Wolf, G. Chem. Ber. 1986, 119, 1876.

60. Ringom, R.; Benneche, T. Acta Chem. Scand. 1999, 53, 41.

61. Ringom, R.; Benneche, T. J. Fluorine Chem. 1999, 95, 121.

62. Goldsmith, D. J.; Liotta, D. C.; Volmer, M.; Hoekstra, W.; Waykole, L. Tetrahedron 1985, $41,4873$.

63. Cohen, N.; Schaer, B.; Scalone, M. J. Org. Chem. 1992, 57, 5783.

64. Scott, J. W.; Bizzarro, F. T.; Parrish, D. R.; Saucy, G. Helv. Chim. Acta 1976, 59, 290.

65. Cohen, N.; Scott, J. W.; Bizzarro, F. T.; Lopresti, R. J.; Eichel, W. F.; Saucy, G. Helv. Chim. Acta 1978, 61, 837.

66. Tietze, L. F.; Stecker, F.; Zinngrebe, J.; Sommer, K. M. Chem. Eur. J. 2006, 12, 8770.

67. Hernández-Torres, G.; Urbano, A.; Carreño, M. C.; Colobert, F. Org. Lett. 2009, 11, 4930.

68. Mizuguchi, E.; Achiwa, K. Chem. Pharm. Bull. 1997, 45, 1209.

69. Labrosse, J.-R.; Poncet, C.; Lhoste, P.; Sinou, D. Tetrahedron: Asymmetry 1999, 10, 1069.

70. Trost, B. M.; Shen, H. C.; Dong, L.; Surivet, J.-P. J. Am. Chem. Soc. 2003, 125, 9276.

71. Orita, A.; Tanahashi, C.; Kakuda, A.; Otera, J. J. Org. Chem. 2001, 66, 8926.

72. Clark, D. A.; Goldstein, S. W.; Volkmann, R. A.; Eggler, J. F.; Holland, G. F.; Hulin, B.; Stevenson, R. W.; Kreutter, D. K.; Gibbs, E. M.; Krupp, M. N.; Merrigan, P.; Kelbaugh, P. L.; Andrews, E. G.; Tickner, D. L.; Suleske, R. T.; Lamphere, C. H.; Rajeckas, F. J.; Kappeler, W. H.; McDermott, R. E.; Hutson, N. J.; Johnson, M. R. J. Med. Chem. 1991, 34, 319.

73. Kamat, V. S.; Graden, D. W.; Lynn, D. G. Tetrahedron Lett. 1982, 23, 1541.

74. Kimura, M.; Fujimatsu, H.; Ezoe, A.; Shibata, K.; Shimizu, M.; Matsumoto, S.; Tamaru, Y. Angew. Chem. Int. Ed. 1999, 38, 397.

75. Kimura, M.; Ezoe, A.; Tanaka, S.; Tamaru, Y. Angew. Chem. Int. Ed. 2001, 40, 3600.

76. Liang, S.; Paquette, L. A. Acta Chem. Scand. 1992, 46, 597. 
77. Kaliappan, K.; Subba Rao, G. S. R. J. Chem. Soc., Perkin Trans. 1 1997, 3387.

78. Green, J. C.; Pettus, T. R. R. J. Am. Chem. Soc. 2011, 133, 1603.

79. Selenski, C.; Pettus, T. R. R. J. Org. Chem. 2004, 69, 9196.

80. For another use of the Wittig reaction in the terpenes chemistry, see : Harrowven, D. C.; Wilden, J. D.; Tyte, M. J.; Hursthouse, M. B.; Coles, S. J. Tetrahedron Lett. 2001, 42, 1193.

81. Scarborough, R.; Kalaritis, P.; Steenrod, J. G.; Yiannikouros, G. PCT Int. Appl. 87871, 2001; Chem. Abstr. 2001, 135, 371634. In this patent, preparations are described on a pilot scale.

82. Antoine, L.; Bouquel, P.; Borghese, A.; Fisher, M.; Gorissen, H.; Jakubowski, J. A.; Khau, V. V.; Martinelli, M.; Merschaert, A.; Paal, M.; Ruhter, G. PCT Int. Appl. 94333, 2001; Chem. Abstr. 2001, 136, 37511.

83. Antoine, L.; Bouquel, P.; Borghese, A.; Gorissen, H.; Martinelli, M.; Merschaert, A.; Ruhter, G.; Rypens, C.; Scarborough, R. PCT Int. Appl. 94331, 2001; Chem. Abstr. 2001, $136,37510$.

84. Fisher, M. J.; Happ, A. M.; Jakubowski, J. A.; Kinnick, M. D.; Kline, A. D.; Martinelli, M. J.; Morin Jr., J. M.; Paal, M.; Rühter, G.; Ruterbories, K. J.; Sall, D. J.; Schotten, T.; Skelton, M. A.; Stenzel, W.; Vasileff, R. T. US Patent 5731 324, 1998; Chem. Abstr. 1998, 128, 257341.

85. Antoine, L.; Bouquel, P.; Borghese, A.; Gorissen, H.; Khau, V. V.; Martinelli, M.; Merschaert, A.; Ruhter, G.; Rypens, C. PCT Int. Appl. 94334, 2001; Chem. Abstr. 2001, 136, 37512.

86. Kanter, J.; Mullins, J. J. G.; Scarborough, R.; Walker, D.; Hense, T. U.S. Patent 6855 833, 2005.

87. Merschaert, A.; Delbeke, P.; Daloze, D.; Dive, G. Tetrahedron Lett. 2004, 45, 4697.

88. Cheng, X.-M.; Filzen, G. F.; Geyer, A. G.; Lee, C.; Trivedi, B. K. U.S. Patent Appl. 0207915, 2003.

89. Pahadi, N. K.; Paley, M.; Jana, R.; Waetzig, S. R.; Tunge, J. A. J. Am. Chem. Soc. 2009, 131, 16626.

90. Amos, R. I. J.; Gourlay, B. S.; Molesworth, P. P.; Smith, J. A.; Sprod, O. R. Tetrahedron 2005, 61, 8226.

91. Jacobi, P. A.; Li, Y. J. Am. Chem. Soc. 2001, 113, 9307.

92. Ragno, R.; Marshall, G. R.; Di Santo, R.; Costi, R.; Massa, S.; Rompei, R.; Artico, M. Bioorg. Med. Chem. 2000, 8, 1423.

93. Wilkinson, J.; Foretia, D.; Rossington, S.; Heagerty, A.; Leonard, J.; Hussain, N.; Austin, C. Eur. J. Pharmacol. 2007, 561, 160.

94. Wilkinson, J. A.; Rossington, S. B.; Coe, N. A.; Hirst, N.; McGown, A. T.; Leonard, J.; Hussain, N. Lett. Drug. Des. Discov. 2007, 4, 246.

95. Lennon, P. J.; Bonafoux, D. F.; Wolfson, S. G. PCT Int. Appl. 091607, 2004; Chem. Abstr. 2004, 141, 379634. 
96. Ulgheri, F.; Marchetti, M.; Piccolo, O. J. Org. Chem. 2007, 72, 6056.

97. For other preparations of $(R)-\mathbf{1 4 0}$, see Chen, G.; Tokunaga, N.; Hayashi, T. Org. Lett. 2005, 7, 2285 and reference 79.

98. Carling, R. W.; Leeson, P. D.; Moseley, A. M.; Smith, J. D.; Saywell, K.; Trickelbank, M. D.; Kemp, J. A.; Marshall, G. R.; Foster, A. C.; Grimwood, S. Bioorg. Med. Chem. 2003, 3, 65 .

99. Takeda, Y.; Nakabayashi, T.; Shirai, A.; Fukumoto, D.; Kiguchi, T.; Naito, T. Tetrahedron Lett. 2004, 45, 3481.

100. Li, Z.; Zhang, J.; Li, C.-J. Tetrahedron Lett. 2003, 44, 153.

101. Batey, R. A.; Powell, D. A.; Acron, A.; Lough, A. J. Tetrahedron Lett. 2001, 42, 7935.

102. Bissel, P.; Nazih, A.; Sablong, R.; Lepoittevin, J. P. Org. Lett. 1999, 1, 1283.

103. Selenski, C.; Mejorado, L. H.; Pettus, T. R. R. Synlett 2004, 1101.

\section{Authors' Biographies}

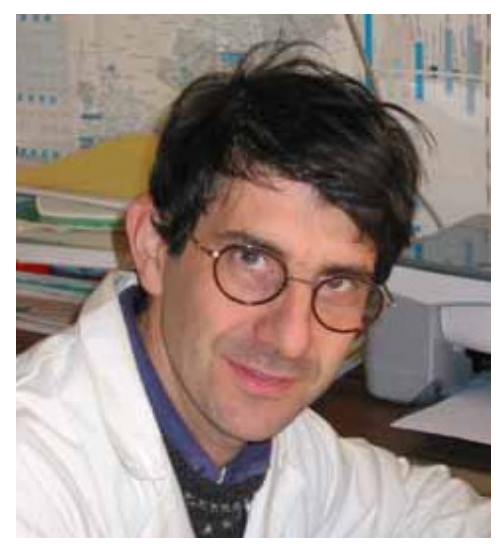

JM Mattalia received his $\mathrm{PhD}$ in 1992 at the Faculty of Saint-Jérôme in Marseille under the supervision of Professor Michel Chanon. After posdoctoral studies in the group of Prof. CJM Stirling at the University of Sheffield, he joined the Aix-Marseille University as assistant professor. His main research interests are in the field of mechanism studies and heterocyclic chemistry. 


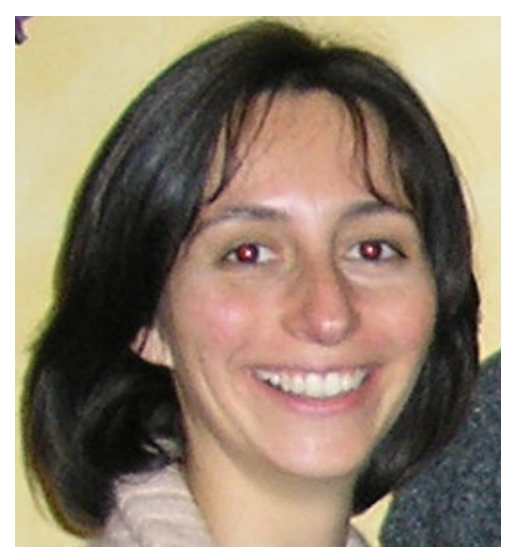

M Attolini received her $\mathrm{PhD}$ in organic chemistry under the guidance of Prof Michel Maffei and Prof Gilbert Peiffer at the University of Aix-Marseille in 2000. She was a postdoctoral fellow at Louvain-la-Neuve University with Prof Marchand-Brynaert. Then she joined the Aix Marseille University as associate professor. Her research interests include heterocyclic chemistry, catalysis and synthesis of new organophosphorus compounds. 